\title{
Real-case simulations of aerosol-cloud interactions in ship tracks over the Bay of Biscay
}

\author{
A. Possner ${ }^{1}$, E. Zubler ${ }^{2}$, U. Lohmann ${ }^{1}$, and C. Schär ${ }^{1}$ \\ ${ }^{1}$ Institute for Atmospheric and Climate Science, ETH Zurich, Zurich, Switzerland \\ ${ }^{2}$ Federal Office of Meteorology and Climatology MeteoSwiss, Zurich, Switzerland \\ Correspondence to: A. Possner (anna.possner@env.ethz.ch)
}

Received: 18 September 2014 - Published in Atmos. Chem. Phys. Discuss.: 24 October 2014

Revised: 21 January 2015 - Accepted: 31 January 2015 - Published: 27 February 2015

\begin{abstract}
Ship tracks provide an ideal test bed for studying aerosol-cloud interactions (ACIs) and for evaluating their representation in model parameterisations. Regional modelling can be of particular use for this task, as this approach provides sufficient resolution to resolve the structure of the produced track including their meteorological environment whilst relying on the same formulations of parameterisations as many general circulation models. In this work we simulate a particular case of ship tracks embedded in an optically thin stratus cloud sheet which was observed by a polar orbiting satellite at 12:00 UTC on 26 January 2003 around the Bay of Biscay.

The simulations, which include moving ship emissions, show that the model is indeed able to capture the structure of the track at a horizontal grid spacing of $2 \mathrm{~km}$ and to qualitatively capture the observed cloud response in all simulations performed. At least a doubling of the cloud optical thickness was simulated in all simulations together with an increase in cloud droplet number concentration by about $40 \mathrm{~cm}^{-3}(300 \%)$ and decrease in effective radius by about $5 \mu \mathrm{m}(40 \%)$. Furthermore, the ship emissions lead to an increase in liquid water path in at least $25 \%$ of the track regions.

We are confident in the model's ability to capture key processes of ship track formation. However, it was found that realistic ship emissions lead to unrealistic aerosol perturbations near the source regions within the simulated tracks due to grid-scale dilution and homogeneity.

Combining the regional-modelling approach with comprehensive field studies could likely improve our understanding of the sensitivities and biases in ACI parameterisations, and
\end{abstract}

could therefore help to constrain global ACI estimates, which strongly rely on these parameterisations.

\section{Introduction}

Since their discovery in satellite imagery, ship tracks have been viewed as convincing evidence of aerosol-cloud interactions (ACIs) occurring in shallow, marine planetary boundary layers (PBLs). Their exclusive existence within a narrow range of environmental conditions despite vast global emissions of ship exhaust has inspired a wide field of experimental and modelling research on the influence of aerosol perturbations on cloud microphysics and the marine PBL state. Since marine shallow clouds are particularly effective in modulating the radiative budget as well as the hydrological cycle (Stevens and Feingold, 2009), the role of anthropogenic emissions for these clouds is of particular interest not only for process understanding, but also for climate impacts.

In particular it has been shown in both satellite observations (Christensen and Stephens, 2011; Chen et al., 2012; Goren and Rosenfeld, 2012) and modelling studies (Wang et al., 2011; Kazil et al., 2011; Berner et al., 2013) that changes in the background aerosol and cloud condensation nuclei $(\mathrm{CCN})$ concentrations not only affect the cloud albedo by producing more numerous and smaller cloud droplets (Twomey effect, 1974), but may also induce transitions between cloud regimes, which fundamentally change the boundary layer state.

While CCN injections were found to induce transitions from open- to closed-cell stratocumulus by suppressing drizzle formation (Wang et al., 2011; Goren and Rosenfeld, 
2012), the converse was simulated in the case of aerosol depletion by precipitation. The scarcity of $\mathrm{CCN}$ induced the collapse of the boundary layer and a break-up of the stratocumulus cloud deck into an open cell structure with scattered, drizzling shallow cumuli (Ackerman et al., 1993; Wood et al., 2011; Berner et al., 2013).

Despite significant impacts of ship tracks on the regional and local scale, their radiative forcing on the global scale was found to be insignificant due to their rare occurrence (Schreier et al., 2007; Peters et al., 2011, 2014). Assessing the global effects of ACIs due to ship emissions in general and their relevance to climate has been challenging in both satellite observations and global models. Peters et al. (2011) found no statistically significant impacts on large-scale cloud fields by shipping emissions using satellite observations. However, due to the large natural variability within the cloud systems which might mask potentially relevant ACIs, satellite observations (Peters et al., 2014) could not exclude their existence either.

Global general circulation model (GCM) simulations yield globally averaged ACIs due to ship emissions between -0.6 and $-0.07 \mathrm{Wm}^{-2}$ (Lauer et al., 2007; Righi et al., 2011; Peters et al., 2012; Partanen et al., 2013). Given the maximum simulated cooling effect, ACI induced by shipping emissions could significantly contribute to the current best estimate of globally averaged ACI $\left(-0.45 \mathrm{Wm}^{-2}\right.$, Myhre et al., 2013). However, ACI are represented in GCMs by parameterisations, which are highly uncertain. Combined with the limited ability of GCMs to simulate mesoscale circulations and low clouds in general (Nam et al., 2012), these estimates can be given with limited confidence only.

In order to gain a more detailed understanding of the parameterised cumulative response of dynamical and microphysical processes to aerosol perturbations by ship emissions, we consider the regional modelling approach. While both boundary layer and microphysical processes are represented by similar parameterisations in regional models as in GCMs, one should be able to capture the structure of a ship track at kilometre-scale resolution. Therefore, this approach allows for a direct comparison of the simulated ACI to observations and can hence aid significantly to constrain the realism of the parameterised response.

In this study we use the regional COSMO model to simulate the most prominent case of ship tracks observed over Europe by the MODIS satellite on 26 January 2003. At 12:00 UTC, the polar-orbiting satellite passed over this region and captured ship tracks embedded within optically thin stratus (optical thickness $\tau \leq 2$ ) west of the Bay of Biscay (see Fig. 1). From the satellite image one can deduce further information on the background conditions of the boundary layer.

Based on the structures of open cells underneath the optically thin cloud layer visible in the MODIS image, one can infer the cloud to be drizzling. To the east of the ship track region, a closed stratocumulus deck without any ship track signal was observed. This is consistent with our current understanding of the susceptibility of different cloud systems to aerosol perturbations (Stevens and Feingold, 2009). While drizzling boundary layers of little cloud water have previously been identified as susceptible to aerosol perturbations, optically thick non-precipitating stratocumulus sheets are known to buffer the response to the aerosol perturbation (e.g. Coakley et al., 1987; Stevens and Feingold, 2009; Chen et al., 2012; Christensen and Stephens, 2012).

Furthermore the presence of the optically thin stratus suggests the boundary layer to be weakly mixed in this region as the cloud top radiative cooling is small. This is supported by soundings at the French coast at Brest, which display a collapsed boundary layer structure with a strong inversion of $12 \mathrm{~K}$ at $500 \mathrm{~m}$ on 27 January 2003 at 00:00 UTC (Possner et al., 2014). The collapse of the marine boundary layer with a remnant stratified thin cloud layer has been found to coincide with aerosol deprived clean background conditions due to precipitation scavenging of $\mathrm{CCN}$ where cloud droplet numbers can be as low as $1-10 \mathrm{~cm}^{-3}$ (Ackerman et al., 1993; Wood et al., 2011; Berner et al., 2013).

In these simulations the response of the aerosol and cloud bulk microphysics parameterisations to the ship emissions are quantified and discussed in the context of the MODIS observation and other ship track measurements from the literature. Additionally, parameterised boundary layer processes, such as PBL tracer transport, are discussed as well as the impact of the ship exhaust on the PBL structure.

\section{Methods}

\subsection{Model description}

The simulations were carried out with the COSMO model, developed and maintained by the COSMO consortium. The COSMO model (version 4.14) is a state-of-the-art, nonhydrostatic model used at $2 \mathrm{~km}$ horizontal resolution with a time step of $20 \mathrm{~s}$. A vertical resolution of at most (resp. at least) $150 \mathrm{~m}(20 \mathrm{~m})$ in the PBL was used. The fully compressible flow equations are solved using a third-order RungeKutta discretisation in time (Wicker and Skamarock, 2002; Foerstner and Doms, 2004). Vertical advection is computed using an implicit second-order centred scheme and horizontal advection is solved using a fifth-order upstream discretisation. Tracers, such as the hydrometeors and aerosol species, are advected horizontally using a second-order Bott scheme (Bott, 1989). The turbulent fluxes are represented using a 1-D turbulent diffusion scheme with a prognostic description for the turbulent kinetic energy. The minimum threshold for the eddy diffusivity intrinsic to the turbulence parameterisation is set to $0.01 \mathrm{~m}^{2} \mathrm{~s}^{-1}$ (Possner et al., 2014). Shallow convection is described using the Tiedtke (1989) mass flux scheme without precipitation production with an entrainment rate of $3 \times 10^{-4} \mathrm{~m}^{-1}$. The radiative transfer is 


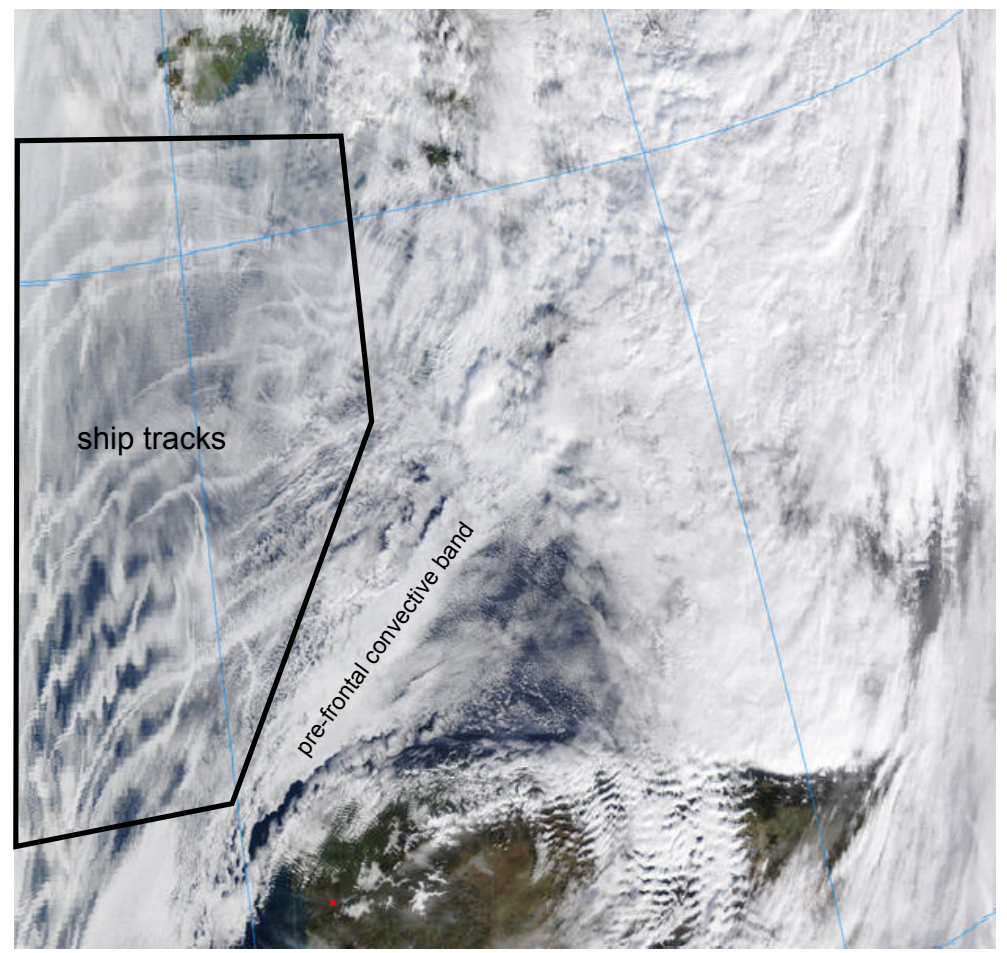

Figure 1. True-colour MODIS satellite image (wavelength bands 670, 565 and $479 \mathrm{~nm}$ ) on 26 January 2003 at 12:00 UTC of the Bay of Biscay. Note the numerous ship tracks in the northwest of the image and the pre-frontal band of convection stretching across the Bay.

based on a $\delta$-two-stream approach (Ritter and Geleyn, 1992) using a relative humidity criterion for subgrid-scale cloud cover.

In previous work the model was extended with a twomoment bulk cloud microphysics scheme (Seifert and Beheng, 2006) and the M7 aerosol microphysics scheme (Vignati et al., 2004; Zubler et al., 2011). The aerosol microphysics scheme describes the evolution of black carbon (BC), organic carbon (OC), sulfate $\left(\mathrm{SO}_{4}\right)$, sea salt and dust. These species are binned into four internally mixed soluble and three insoluble modes determined by fixed size ranges (nucleation, Aitken, accumulation and coarse). The processes relevant to this study captured by the model include condensation of sulfuric acid vapour, hydration, coagulation, sedimentation as well as dry and wet deposition of aerosol particles. The soluble aerosol particles are activated according to Lin and Leaitch (1997). All soluble aerosol particles in the accumulation $(50 \mathrm{~nm} \leq R \leq 0.5 \mu \mathrm{m})$ and coarse $(R>$ $0.5 \mu \mathrm{m})$ mode, as well as Aitken mode $(5 \mathrm{~nm} \leq R \leq 50 \mathrm{~nm})$ aerosol particles larger than $35 \mathrm{~nm}$ radius are considered as activated. Although there exist more physical activation parameterisations (e.g. Abdul-Razzak and Ghan, 2000; Nenes and Seinfeld, 2003), using this simpler form of activation is still in good agreement with observations, which found the $\mathrm{CCN}$ concentration to scale linearly with the soluble accumulation mode number concentration (Wood, 2012 and references therein). The number of newly activated cloud droplets is then further restricted by the available moisture content and the updraft velocity (Lohmann, 2002).

The cloud microphysical processes for cloud droplets and rain described by the Seifert and Beheng (2006) parameterisation contain the growth by condensation, self-collection of cloud droplets and rain drops, autoconversion, accretion, droplet breakup, sedimentation of rain and evaporation (saturation adjustment is applied). The grid-scale cloud optical properties are parameterised as a function of wavelength using the effective droplet radius (Hu and Stamnes, 1993).

\subsection{Numerical experiments}

The dynamical settings and nesting approach used in these simulations are based on the setup of Possner et al. (2014). We use a one-way nesting approach, where the $2 \mathrm{~km}$ simulation $(\Delta t=20 \mathrm{~s})$ is nested in a $12 \mathrm{~km}$ simulation $(\Delta t=90 \mathrm{~s})$ run over a larger domain stretching from the northeast Atlantic to the eastern borders of Switzerland and Germany (see Fig. 1 of Possner et al., 2014). The initial and lateral boundary conditions for the dynamical fields are provided by the ECMWF Interim Reanalysis (Uppala et al., 2005; Dee et al., 2011). For the aerosol tracers, the climatological means for January (1999-2009) obtained in ECHAMHAM simulations (Folini and Wild, 2011) are prescribed as initial and lateral boundary conditions. The global simulations were performed with a two-moment bulk scheme for aerosol (Stier et al., 2005) and cloud (Lohmann et al., 2007) 
microphysics with prescribed aerosol and precursor emissions from the Japanese National Institute for Environmental Studies (NIES, Roeckner et al., 2006; Stier et al., 2006; Nozawa et al., 2007).

In the present simulations, anthropogenic aerosol emissions, excluding ship emissions, are given by the AeroCom data set (Kinne et al., 2006). Natural emissions such as dimethylsulfide (DMS) emissions (Zubler et al., 2011) and sea salt (Guelle et al., 2001) emissions are computed interactively.

\subsubsection{Shipping emissions}

By combustion of low-quality fuel ships emit gases such as $\mathrm{SO}_{2}, \mathrm{NO}_{2}$, hydrocarbons and carbon monoxide, and particulate matter (PM) such as $\mathrm{SO}_{4}, \mathrm{OC}, \mathrm{BC}$ and ash into the atmosphere.

However, of the gaseous emissions only $\mathrm{SO}_{2}$ is considered in this study, which focuses solely on aerosol-cloud interactions (ACI) of ship emissions. Although emitted hydrocarbons, as well as $\mathrm{CO}$, lead to significant increases of greenhouse gas concentrations $\left(\mathrm{CH}_{4}\right.$ and $\mathrm{CO}_{2}$ respectively), their contribution to aerosol mass and number concentrations is small (Murphy et al., 2009). As the secondary aerosol formation of nitrates in sulfur-rich emissions is also very small ( $\mathrm{Vu}-$ tukuru and Dabdub, 2008; Murphy et al., 2009), $\mathrm{NO}_{2}$ emissions were not prescribed. Furthermore, ash emissions are also not included as ash particles are too small in number due to their large size $(\sim 200 \mathrm{~nm}$ to $10 \mu \mathrm{m}$, Moldanová et al., 2009 ) to contribute significantly to the $\mathrm{CCN}$ concentration and were not measured in the two field campaigns (Hobbs et al., 2000; Lack et al., 2009) used for the emission specification of this study.

The emission fluxes used in this study are based on measurements of cargo ship emissions obtained in the Monterey Area Ship Track campaign (Hobbs et al., 2000). Cargo ships, such as tankers, bulk carriers, container and passenger ships larger than 100 gross tons, contribute to $50 \%$ of the global fleet and are the major source of global shipping emissions (Corbett, 2003). The PM emission fluxes for $\mathrm{BC}, \mathrm{OC}$ and $\mathrm{SO}_{4}$ are based on the mean PM particle number emission flux of five different cargo vessel measurements (Hobbs et al., 2000). The mean total particle number flux $\left(9 \times 10^{15} \mathrm{~s}^{-1}\right)$ was chosen, as individual emission measurements themselves varied by more than a factor of 2 between the individual vessels. The PM mass flux was estimated using the total particle number flux and estimates of emission size and density. For each of the five considered ships, the median emission radius was provided by Hobbs et al. (2000). The averaged median radius $(0.04 \mu \mathrm{m})$ was used as the emission size estimate for all particles. Together with the density estimate, which was taken as the mean density across all involved constituents $\left(\sim 1.95 \mathrm{~g} \mathrm{~cm}^{-3}\right)$, the PM mass flux was approximated as $20.84 \mathrm{~kg} \mathrm{~h}^{-1}$. In a final step the emission fluxes for OC $\left(9.59 \mathrm{kgh}^{-1}\right), \mathrm{BC}\left(3.13 \mathrm{~kg} \mathrm{~h}^{-1}\right)$
Table 1. Specifications of the two size distributions used for ship emission fluxes obtained from Righi et al. (2011). The ship emissions are treated as lognormal size distributions and are partitioned into the soluble Aitken (AIT) and accumulation (ACC) modes based on the mass percentage at the mean radius $\bar{R}$.

\begin{tabular}{lccccc}
\hline & \multicolumn{2}{c}{ Fresh } & & \multicolumn{2}{c}{ Aged } \\
\cline { 2 - 3 } \cline { 5 - 6 } & AIT & ACC & & AIT & ACC \\
\hline $\bar{R}[\mu \mathrm{m}]$ & 0.015 & - & & 0.029 & 0.16 \\
$\%[$ mass $]$ & 100 & 0 & & 96 & 4 \\
\hline
\end{tabular}

and $\mathrm{SO}_{4}\left(8.13 \mathrm{~kg} \mathrm{~h}^{-1}\right)$ were determined using the mass fractions of ship emissions measured by Lack et al. (2009). The $\mathrm{SO}_{2}$ emission flux $\left(144 \mathrm{~kg} \mathrm{~h}^{-1}\right)$ was inferred from Hobbs et al. (2000) by averaging the five vessel measurements.

In the present simulations, the $\mathrm{PM}$ and $\mathrm{SO}_{2}$ emission mass fluxes were emitted in one level $\sim 160 \mathrm{~m}$ above the surface (e.g. Peters et al., 2012) with a log-normal size distribution $(\sigma=1.59)$ and two different size specifications (Righi et al., 2011; Lund et al., 2012) shown in Table 1. Both size distributions, fresh and aged, are inferred from measurements and attempt to include coagulation effects of the aerosol as time progresses. They differ in the partitioning of the emission fluxes between the Aitken and the accumulation size modes. Whereas the size distribution of the fresh emissions is representative for emissions at the ship's exhaust where all aerosol particles are emitted into the Aitken mode, the aged size distribution represents older emissions where coagulation processes occurred and the aerosol particles are split into the Aitken (96\%) and accumulation (4\%) modes.

We prescribe three ships starting at 03:00 UTC on 26 January 2003 at the same longitude at the edge of the Bay of Biscay, arbitrarily separated in their initial position in the latitude by $50 \mathrm{~km}$ (between the northernmost and middle ship) and $80 \mathrm{~km}$ (between middle and southernmost ship). All ships move southwest at $230^{\circ}\left(0^{\circ}\right.$ pointing north $)$ at 5 , 10 , or $20 \mathrm{~m} \mathrm{~s}^{-1}$. For numerical stability the ship exhaust is not emitted into a single grid box, but distributed horizontally into four adjacent grid boxes (Fig. 2), based on the ship's exact location, scaled by the distance-weighted mean.

Whilst all boundary fields are updated at an hourly rate, the ship emission fields are updated every 3 minutes. For each 3minute interval the ship emissions are accumulated within the four adjacent grid points around the instantaneous ship position.

The performed simulations, summarised in Table 2, include a control run (clean) where the contribution of shipping emissions is zero and a simulation where the ship emissions are specified as described above (ship). As discussed in detail in Sect. 3.1, the emission flux by Hobbs et al. (2000) generated smaller aerosol perturbations near the emission source in the ship simulation than the measurements of aerosol number concentration obtained in the same study. We therefore 


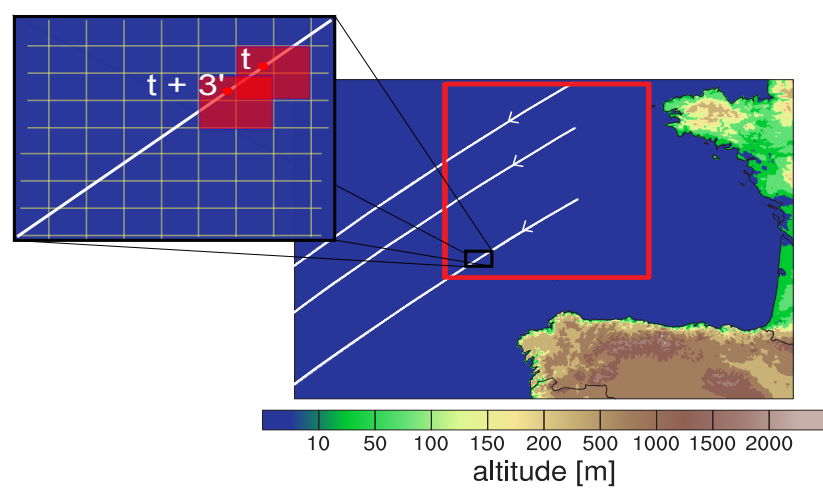

Figure 2. $2 \mathrm{~km}$ simulation domain of $1160 \mathrm{~km} \times 800 \mathrm{~km}$ showing three prescribed ship routes oriented from northeast to southwest. A schematic of the distribution of the ship emissions along the $2 \mathrm{~km} \times 2 \mathrm{~km}$ grid is given inside the black box. The emissions are distributed at a $3 \mathrm{~min}(1.5 \mathrm{~min})$ interval within four adjacent grid boxes along the ship's route for ships moving at 5 or $10 \mathrm{~ms}^{-1}$ $\left(20 \mathrm{~ms}^{-1}\right)$. The red box displays the ship track domain used in Figs. 3-7 and 9. (Note that the ship plume locations shown in these figures are determined by the relative motion between the ships and the horizontal wind.)

Table 2. Summary of ship emission specifications as prescribed in the simulations. Prescribed $\mathrm{SO}_{2}$ and $\mathrm{PM}$ mass fluxes based on the literature (Hobbs et al., 2000) are given together with prescribed size distributions and ship's speed $\left(v_{\text {ship }}\right)$.

\begin{tabular}{lcccc}
\hline Simulation & $\begin{array}{c}\mathrm{SO}_{2} \text { flux } \\
{\left[\mathrm{kg} \mathrm{h}^{-1}\right]}\end{array}$ & $\begin{array}{c}\mathrm{PM} \text { flux } \\
{\left[\mathrm{kg} \mathrm{h}^{-1}\right]}\end{array}$ & $\begin{array}{c}\text { Size } \\
\text { distribution }\end{array}$ & $\begin{array}{c}v_{\text {ship }} \\
{\left[\mathrm{m} \mathrm{s}^{-1}\right]}\end{array}$ \\
\hline clean & - & - & - & - \\
ship & 144 & 20.84 & fresh & 10 \\
ship10 & 144 & 208.4 & fresh & 10 \\
ship10A & 144 & 208.4 & aged & 10 \\
ship10_V5 & 144 & 208.4 & fresh & 5 \\
ship10_V20 & 144 & 208.4 & fresh & 20 \\
\hline
\end{tabular}

perform experiments with scaled emission mass fluxes by a factor 10 (ship10). A scaling of similar order of magnitude has been applied in a previous study performed at considerably higher resolution, where the aerosol perturbation generated by emissions from Hobbs et al. (2000) were found to be insufficient to create a significant cloud response (Wang and Feingold, 2009).

The necessity for such a scaling may be due to the dilution of a point source emission onto the grid scale, which may lead to a biased representation of the subsequent microphysical processing of the plume. However, it may also be needed due to possible measurement biases, which are particularly likely to occur near the emission source, as the aerosol concentrations vary rapidly with the plume's cross-sectional radius in this part of the plume.

In addition, the sensitivity towards the emission particle size is investigated in ship10A, where the aged emis- sion size distribution is prescribed. Furthermore, simulations with varied ship speeds are performed in order to understand the balance of the macrophysical constraints (e.g. cloud cover and moisture availability) and the microphysical feedbacks involved in determining the extent of the ship tracks. Whereas the ships move at $10 \mathrm{~m} \mathrm{~s}^{-1}$ in most simulations, the ships' speed was set to $5 \mathrm{~m} \mathrm{~s}^{-1}$ in ship $10 \_V 5$ and $20 \mathrm{~m} \mathrm{~s}^{-1}$ in ship10_V20. In doing so, one can assess the influence of the ship's speed on the track structure.

\subsection{Classification of ship plume}

In order to quantify the changes in microphysical entities, a distinction between plume and non-plume grid points has to be made in the post-processing. As the only perturbation in total aerosol number concentration $N_{\mathrm{a}}$ is caused by ship emissions, we defined a relative threshold concentration of $N_{\mathrm{a}}$ at each grid point to determine the plume points. Only points where $N_{\mathrm{a}_{\text {simulation }}} \geq 3 N_{\mathrm{a}_{\text {clean }}}$ are considered part of the ship exhaust plume. This threshold provides the required balance of being small enough to include a maximum number of plume points and being large enough to separate the core track structures from surrounding increases of $N_{\mathrm{a}}$ due to aerosol being mixed away from the track region.

Another sampling was performed to determine not only the plume points, but the subset of plume points where a significant cloud response was detected. Here, the additional criterion in terms of cloud droplet number concentration $N_{\mathrm{c}}$ of $N_{\mathrm{c}_{\text {simulation }}} \geq 5 N_{\mathrm{c}_{\text {clean }}}$ was applied.

The ability to distinguish plume from non-plume points and ship track from non-ship-track points of these criteria is shown in Sect. 3.4.

\subsection{Evaluation of cloud optical thickness}

A simple metric to compare simulated cloud optical thickness to the MODIS observation was designed, as the COSP simulator (Bodas-Salcedo et al., 2011), including grid-scale and subgrid-scale cloud water contributions, is not yet available within COSMO.

Cloud optical thickness $\tau$ within COSMO is diagnosed for each of the eight spectral intervals (three shortwave and five longwave) in the radiation scheme. For warm-phase clouds $\tau$ is given as

$\tau\left(x, y, \lambda_{i}\right)=\int_{0}^{\mathrm{TOA}} \xi\left(\lambda_{i}\right) q_{\mathrm{c}_{\mathrm{tot}}}(x, y, z) \mathrm{clc}_{\mathrm{tot}}(x, y, z) \mathrm{d} z$,

where $\xi\left(\lambda_{i}\right)$ denotes the extinction coefficient of each spectral band $\lambda_{i}, q_{\mathrm{c}_{\mathrm{tot}}}$ the total (grid-scale and subgrid-scale) liquid water content at each grid point at coordinates $x$ (longitude), $y$ (latitude) and $z$ (level), and clc tot $_{\text {the cloud cover }}$ fraction (predominantly 0 or 1 in these simulations).

As MODIS cloud optical thickness during day-time and over the ocean is predominantly defined by radiances mea- 
sured within the visible (King et al., 1998; Platnick et al., 2003), the contribution of the visible channel in COSMO $(0.25 \leq \lambda \leq 0.7 \mu \mathrm{m})$ to the total $\tau$ was isolated and used for the MODIS comparison.

\section{Results}

Before a detailed assessment of the ship exhaust effects on the stratocumulus deck is given in the following sections, the background state is described. The mesoscale circulations and the macrophysical state on 26 January are predominantly driven by an extensive high-pressure system with an underlying subsidence rate of about $-0.75 \mathrm{~cm} \mathrm{~s}^{-1}$ at night and $-0.25 \mathrm{~cm} \mathrm{~s}^{-1}$ during daytime at a height of $1.5 \mathrm{~km}$. Temperature gradients of up to $4 \mathrm{~K}$ per $100 \mathrm{~m}$ are simulated within the inversion in the ship track domain (domain shown in Fig. 2). An inversion of this magnitude was only obtained after a significant reduction of the prescribed minimum threshold for the eddy diffusivity of heat and moisture from the operational value of 1.0 to $0.01 \mathrm{~m}^{2} \mathrm{~s}^{-1}$ (Possner et al., 2014). A detailed evaluation using coastal soundings of PBL profiles of horizontal wind, potential temperature $\theta$ and relative humidity and their impact on cloud cover is presented in Possner et al. (2014).

The horizontal large-scale advection of the air masses is dominated by northwesterly flow, pushing air masses from the ship track region towards the continent. During the simulated period a pre-frontal band of organised convection (see Fig. 1) propagates through the domain from the northwest to the east and passes through the ship track domain between 07:00 and 12:00 UTC.

\subsection{Impacts on aerosol microphysics}

The simulated background of this case study is very clean due to the presence of unpolluted marine air into the ship track domain and the removal of aerosol by precipitation. Aerosol concentrations as low as $285 \mathrm{~cm}^{-3}$ and CCN concentrations of $10-20 \mathrm{~cm}^{-3}$ are simulated.

The background aerosol particles are a composite of sea salt emitted within the region and sulfate particles within the Aitken mode, which are transported into the domain from the lateral boundaries. The sulfate particles formed in the midtroposphere and were mixed downward in the driving GCM simulations. Although the aerosol and $\mathrm{CCN}$ concentrations are low, they are not unrealistic for this region (Zubler et al., 2011) or for stratocumulus in general (Wood, 2012) and are consistent with the MODIS observation of optically thin stratus.

The impact of the ship exhaust in all simulations, containing either a varied emission mass flux (ship10) or emission size (ship10A), on the aerosol size distribution is illustrated in Fig. 3. This figure shows the averaged aerosol size distributions determined over a plume volume close to the source at 06:00 UTC and at a distance at 12:00 UTC. The selection method of the included plume grid points of each track is illustrated in Fig. 4. At each of these points the size distribution is determined and then bin-wise averaged over all selected plume points. As in situ size distribution measurements shown in Fig. 3 are obtained within a $10 \mathrm{~km}$ radius of the ship's position, plume points within the same radius of each ship are selected at 06:00 UTC. Furthermore, to ensure a comparison of the same volume of air between different simulations, the plume points considered for this analysis were determined in shiplo and used in all other simulations. In order to visualise size distribution changes along the plume due to dilution and microphysical processing, the distributions were determined again at 12:00 UTC over plume points selected from a volume of air centred at the same latitude as 06:00 UTC (see Fig. 4) which now contains atmospherically aged aerosol particles. To highlight the variability between individual plume points, the span between the 10th and 90th percentiles (P10 and P90 respectively) is shown in addition to the averaged distribution in grey at 06:00 UTC.

In general a good agreement of the peak width is found between all simulations and observations obtained by Hobbs et al. (2000) (Fig. 3 blue markers) and Petzold et al. (2008) (Fig. 3 orange markers), while peak amplitudes are underestimated with respect to the observations in ship and ship10A. Observed peak concentrations in aerosol number per size bin, which vary between $5000 \mathrm{~cm}^{-3}$ and $100000 \mathrm{~cm}^{-3}$ (i.e. over two orders of magnitude), are only captured by the ship10 simulation.

However, it has to be considered that the observations shown in Fig. 3 were obtained within different marine boundary layers of varying background aerosol concentrations, ship emissions (in terms of mass flux and size) and PBL state, and were obtained for considerably smaller samples of air (compared to a $2 \mathrm{~km}$ by $2 \mathrm{~km}$ by $100 \mathrm{~m}$ volume) at different plume ages. As all of these factors influence the plume evolution, complete conformity between the simulated plumes of this case study and the observations is not to be expected. However, a qualitative comparison in terms of order of magnitude can still be made and provides valuable insights.

In addition to size distribution measurements, observations of the total perturbation in aerosol number concentration are also considered. The simulated perturbations in $N_{\mathrm{a}}$ ( $\Delta N_{\mathrm{a}}$ shown in Fig. 3b-d) are compared to measurements obtained by Hobbs et al. (2000) (Fig. 1 of their paper) for a bulk carrier running on marine fuel oil (Star Livorno), which was one of the five ships considered for the ship exhaust estimate of this study. The observations of $\Delta N_{\mathrm{a}}$ range between 3000 and $30000 \mathrm{~cm}^{-3}$. However, only $7 \%$ of the measurements were smaller than $5000 \mathrm{~cm}^{-3}$, while over $50 \%$ were obtained at $\Delta N_{\mathrm{a}}>20000 \mathrm{~cm}^{-3}$. Therefore, peak concentrations of at least $20000 \mathrm{~cm}^{-3}$ in the vicinity of the ship can be inferred.

In the simulations $\Delta N_{\mathrm{a}}$ was determined at each point by taking the difference between any simulation containing ship 

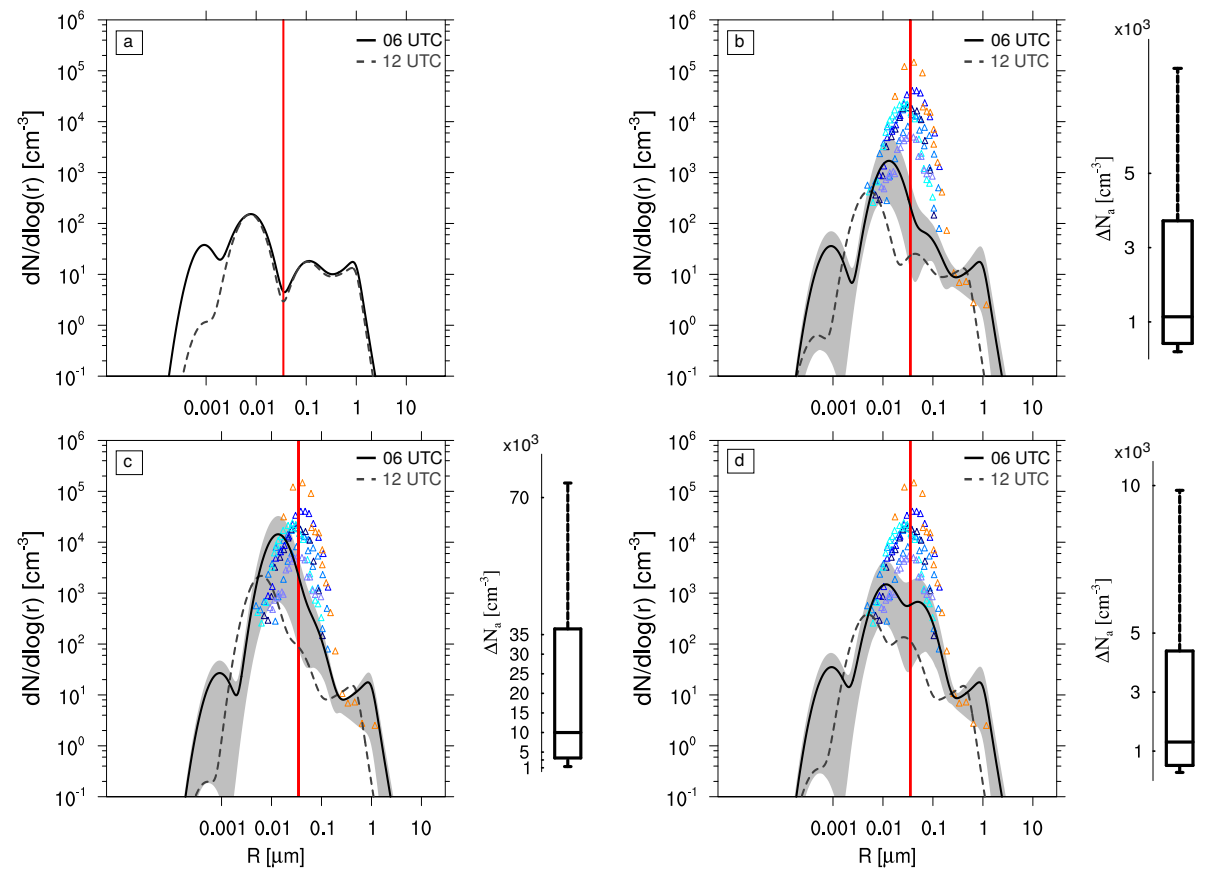

Figure 3. Mean aerosol size distributions of internally mixed aerosol for (a) clean, (b) ship, (c) ship10 and (d) ship10A are shown at 06:00 and 12:00 UTC. At 06:00 UTC size distributions were averaged bin-wise near the emission source and at 12:00 UTC at a distance of 216 km (see text for details). Red line marks the activation size threshold. In panels (b-d): grey shaded region spans between the 10th and 90th percentiles at 06:00 UTC; field study measurements are represented by coloured markers and include five size distribution measurements (different shades of blue) obtained by Hobbs et al. (2000) of vessels and one measurement (orange) obtained by Petzold et al. (2008); box plot representations of the total aerosol perturbation $\left(\Delta N_{\mathrm{a}}\right)$ at 06:00 UTC near the emission source with respect to the background (obtained from clean) are shown in addition (note their different scale).

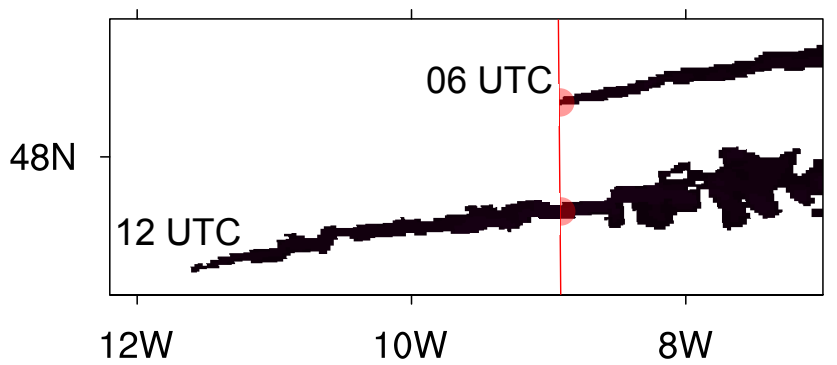

Figure 4. Schematic of selection method for plume points considered for averaged size distributions shown in Fig. 3. Exemplary tracks are shown for 06:00 and 12:00 UTC within the same map. The plume points are sampled at each level within a $10 \mathrm{~km}$ radius (red half circle) at the latitude (red line) defined by the ship's position at 06:00 UTC. Therefore the plume points contain freshly emitted aerosol particles at 06:00 UTC and atmospherically aged aerosol particles at 12:00 UTC.

exhaust and clean over plume points within a $10 \mathrm{~km}$ radius from the source at 06:00 UTC. A comparison between the simulated range of $\Delta N_{\mathrm{a}}$ with the observations shows that almost $75 \%$ of the simulated perturbations are below the observed range. This indicates that the aerosol perturbation due to the literature-scale emission flux might be insufficient to generate comparable peak concentrations within the plume. On the other hand, the simulated range of perturbations as compared to the observations agrees well up to the 75 th percentile (P75) with the observations of ship10. However, this agreement is obtained at the expense of a considerable overestimation of the peak perturbations in this simulation.

In addition to differences in peak amplitude, a shift of the aerosol peak towards smaller radii is detectable between the ship and ship10 simulations and observations. The difference in peak radius is strongly tied to the emission size of the ship exhaust. Whilst an emission size of $0.015 \mu \mathrm{m}$ was specified for fresh plumes (Table 1), ship exhaust radii of at least $0.03 \mu \mathrm{m}$ were measured by Hobbs et al. (2000). While this discrepancy in emission radius was noted, the results of this study were not found to be affected.

The aerosol size distribution in ship 10A displays a distinct double-peak structure due to the bimodal emission size distribution applied (Table 1). While all observations shown in Fig. 3 display a single peak, measurements of double-peak structures have been obtained in test bed studies (Petzold et al., 2008). In terms of $\Delta N_{\mathrm{a}}$, smaller peak perturbations are simulated in ship10A than observed, as the aged emission size distribution was developed to represent older plume segments, which consequentially are more diluted. 

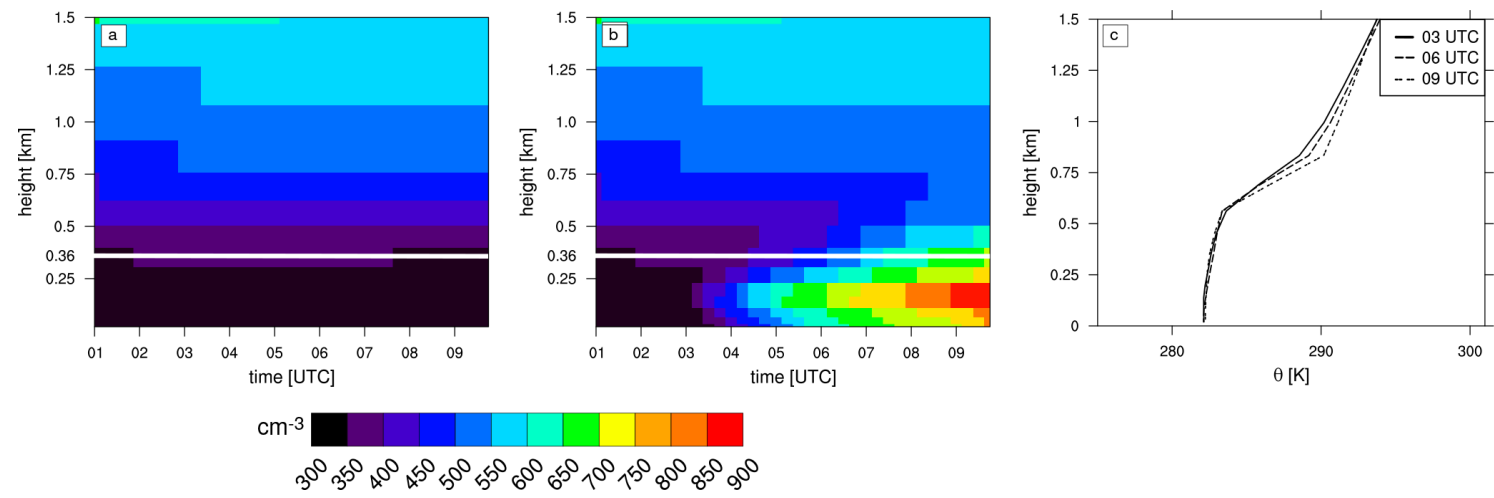

Figure 5. (a-b) Mixed aerosol number concentration $\left[\mathrm{cm}^{-3}\right.$ ] averaged at each level over the ship track domain at a 15 min interval for (a) clean and (b) ship10. The mean cloud base height is shown in white. (c) Potential temperature ( $\theta$ ) profiles at 03:00, 06:00 and 09:00 UTC at the ship track domain centre point.

As time evolves and the growing plumes are increasingly diluted, the in-plume size distributions are increasingly influenced by clean air. Indeed the size distribution peak is found to shift towards the clean aerosol peak position in all simulations (Fig. 3b-d) by 12:00 UTC. In addition the formation of a secondary peak can be observed for ship, which is not simulated to the same extent in ship10. This is caused by the increase of background aerosol concentrations within this size range (Fig. 3a) and their increased impact in ship as compared to shiplo.

In terms of microphysical processing, the most relevant processes include the condensation of sulfate and water vapour onto mixed aerosol particles. The presence of the ship pollutants leads to a suppression of sulfate nucleation due to the abundance of condensation nuclei within the plumes. In combination with efficient scavenging by in-plume aerosol particles, the nucleation mode aerosol concentrations are reduced.

Finally the number of activated particles was found to be strongly tied to the prescribed emission flux and to a lesser extent to emission size. As can be seen in Fig. 3, particle concentrations larger than $35 \mathrm{~nm}$ are similar between ship 10 and ship10A, which are five times as high as the activated aerosol concentrations in ship. However, the percentage of activated particles lies between 3 and $6 \%$ in most of the plume areas, which agrees well with plume measurements obtained at $0.2 \%$ supersaturation (Hudson et al., 2000).

\subsection{Vertical aerosol transport}

After emission at $\sim 160 \mathrm{ma}$ a.s.l., the ship plume aerosols are subject to turbulent and convective boundary layer transport. Figure 5 provides an insight into the vertical distribution of mixed aerosols in clean and ship10. Under clean conditions, the background aerosols (Fig. 5a) are not homogeneously distributed in the mean boundary layer profile. Instead, the aerosol concentration is found to increase from at least $300 \mathrm{~cm}^{-3}$ near the surface to $500 \mathrm{~cm}^{-3}$ near the PBL top in stratified layers. The PBL top, as defined by the inversion, and boundary layer stability, can be inferred from Fig. 5c, which displays the potential temperature $(\theta)$ profile at the centre point of the ship track domain at 03:00, 06:00 and 09:00 UTC. Throughout the first $9 \mathrm{~h}$ of simulation, the PBL remains slightly stable in this region, which allows for persistent vertical gradients in the mixed aerosol concentrations. Higher concentrations of mixed aerosol particles up to $600 \mathrm{~cm}^{-3}$ are reached due to the increased concentration of Aitken mode sulfate above the inversion.

For the formation of ship tracks, the timescale of the ship plume reaching cloud base is of particular interest. The mean cloud base height within the ship track domain between 00:00 and 09:00 UTC was determined at $\sim 360 \mathrm{~m}$, as shown by the white line in Fig. 5a and b. Figure 5b shows the evolution of the mixed aerosol concentration including ship exhaust averaged every $15 \mathrm{~min}$ at each level. As time progresses, the total number concentration increases within the PBL, due to cumulative emissions within this region. From the clearly distinguishable emission height at $\sim 160 \mathrm{~m}$, the aerosol are mixed both downwards towards the surface and upwards towards the PBL top, as expected within a turbulent boundary layer (e.g. Verzijlbergh et al., 2009). At cloud base the mixed aerosol number concentration is first raised from the background concentration of 350 to $420 \mathrm{~cm}^{-3}$ within $1 \mathrm{~h}$ 15 min after emission begin at 03:00 UTC. This timescale is consistent with the timescale estimate obtained for the turbulent mixing of a passive tracer assuming a gradient approach, i.e. $\overline{w^{\prime} c^{\prime}}=-K_{\mathrm{c}} \partial c / \partial z$, where $c$ is the passive tracer concentration, $w^{\prime}$ the turbulent vertical velocity and $K_{\mathrm{c}}$ is the eddy diffusivity of the tracer. Taking $K_{\mathrm{c}} \sim K_{\mathrm{h}}$, the eddy diffusivity for heat, one can estimate $K_{\mathrm{c}}$ as $12.3 \mathrm{~m}^{2} \mathrm{~s}^{-1}$ based on the mean $K_{\mathrm{h}}$ profile for the ship track domain (not shown). Neglecting variations of $K_{\mathrm{c}}$ with height, the overturning time scale within a slab of the atmosphere of extent $\Delta z$ can be approximated as $\tau_{\text {turb }} \sim \Delta z^{2} / K_{\mathrm{h}}$. Therefore taking $\Delta z=200 \mathrm{~m}$, which is the difference in height between 

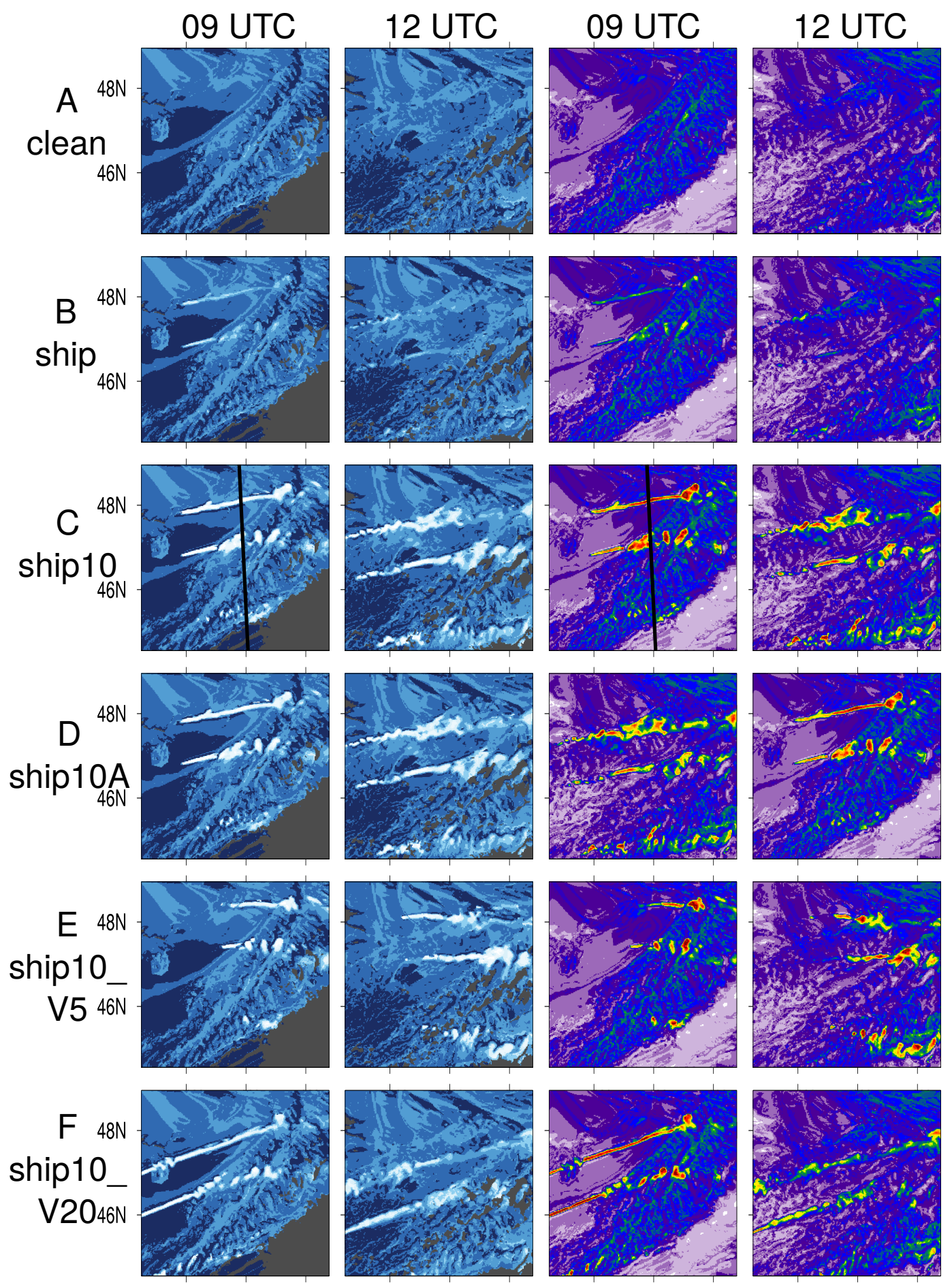

$10 \mathrm{~W} \quad 8 \mathrm{~W} \quad 6 \mathrm{~W}$

10W $8 W \quad 6 W$

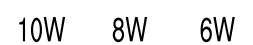

$10 \mathrm{~W} \quad 8 \mathrm{~W} \quad 6 \mathrm{~W}$
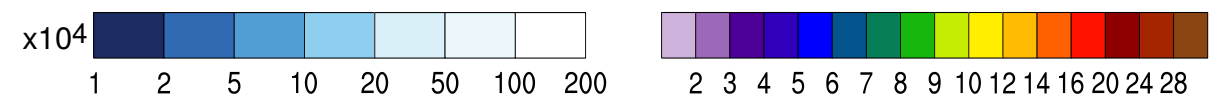

Figure 6. Columns 1 and 2 show grid-scale cloud droplet number burden $\left[\mathrm{cm}^{-2}\right]$ and columns 3 and 4 cloud optical thickness, including grid-scale and subgrid-scale contributions, at 09:00 and 12:00 UTC respectively. Rows (a-f) show the following simulation results: (a) clean, (b) ship, (c) ship10, (d) ship10A, (e) ship10_V5 and (f) ship10_V20. Grey shaded areas in columns 1 and 2 denote regions of missing grid-scale clouds. 

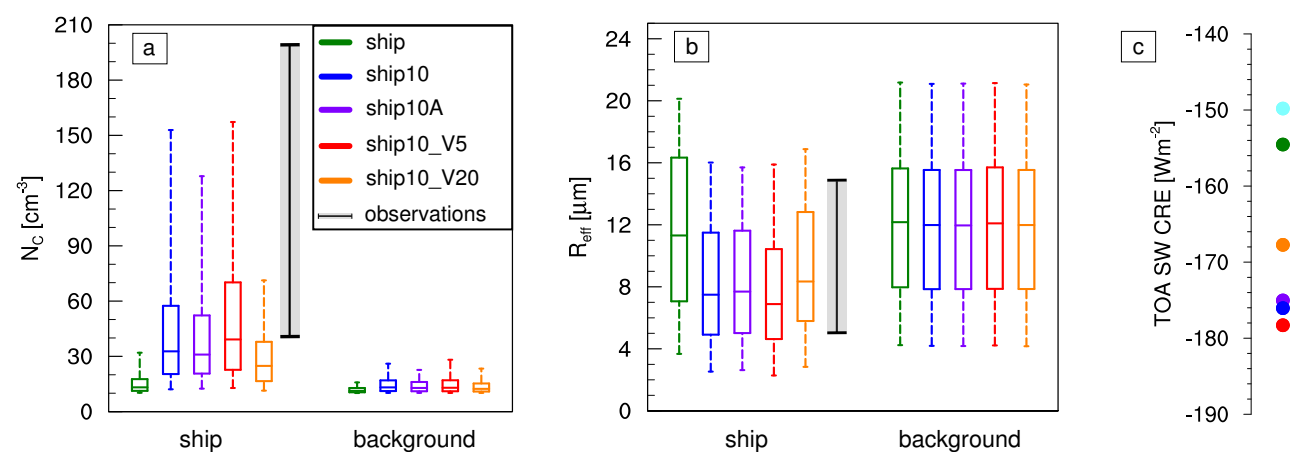

Figure 7. (a-b) Distributions across PBL grid points for either plume points of significant cloud response or environmental background conditions are shown for (a) $N_{\mathrm{c}}$ and (b) $R_{\mathrm{eff}}$ at 12:00 UTC for all simulations containing ship emissions. The box edges denote the 25th and 75th percentiles, and the whiskers display the 5th and 95th percentiles. The plume regions were diagnosed within ship10, ship10_V5 (for ship10_V5 only) and ship10_V20 (for ship10_V20 only). The range of observations is denoted in black. Panel (c) displays the top of the atmosphere (TOA) shortwave (SW) cloud radiative effect (CRE) averaged over the entire ship track region for all simulations (clean is shown in light blue).

the cloud base and emission height, $\tau_{\text {turb }}$ is approximated as $54 \mathrm{~min}$, which agrees well with the timescale obtained from the mean profiles shown in Fig. 5b.

In addition to turbulent transport, a fraction of the ship emissions are transported by convective fluxes into the cloud layer, just below the inversion base. At the level between $500 \mathrm{~m}$ and inversion base height, the mixed aerosol concentrations are raised by $10-15 \mathrm{~cm}^{-3}$ already $30 \mathrm{~min}$ after emission onset. However, turbulent mixing is the predominant form of vertical PBL transport at this time.

Finally, Fig. 5b clearly highlights the confinement of the ship plume to the boundary layer due to the strong inversion. The mixed aerosol concentrations above the PBL remain unaffected by the ship emissions.

\subsection{Microphysical and radiative effects}

The simulated cloud microphysical response to the plumes of increased aerosol concentration was found to be in agreement with findings of previous studies. Within plume regions, the increased number of activated aerosol led to an increase in cloud droplet number concentration and a decrease in effective radius. As a result, the cloud optical thickness increased. The strength of the response is sensitive to the plume's age and intensity (in terms of aerosol number concentration) as well as the environmental conditions, as discussed in Sect. 3.4.

Figure 6 displays the cloud droplet number burden summed over the PBL (columns 1 and 2) and $\tau$ (columns 3 and 4) at 09:00 and 12:00 UTC. For this purpose, the inversion top, which lies at around $800 \mathrm{~m}$, was diagnosed for each column based on the temperature gradient (Possner et al., 2014). Although all simulations display an increase in the cloud droplet burden along the tracks, its extent varies significantly among the different simulations. At 09:00 UTC, the cloud droplet burden is increased up to $120 \times 10^{4} \mathrm{~cm}^{-2}$ within the plume regions in all simulations apart from ship, where maximum burdens of $15 \times 10^{4} \mathrm{~cm}^{-2}$ are simulated. Considering the significantly smaller number of activated aerosol within the plume in ship (Fig. 3b), this is to be expected. After an additional $3 \mathrm{~h}$ of simulation, the tracks have grown in size, but similar values of cloud droplet burden are reached at 12:00 UTC.

In ship10_V20 however, a significant decrease in the cloud droplet burden was simulated down to $20 \times 10^{4} \mathrm{~cm}^{-2}$ until 12:00 UTC. Whilst the ship tracks shown in rows $1-5$ in Fig. 6 form $\sim 25 \mathrm{~km}$ from the source, or even just $\sim 7 \mathrm{~km}$ in ship10_V5, the emission sources are already separated by $313 \mathrm{~km}$ from the track sections displayed within the ship track domain in row 6 at 12:00 UTC, and are therefore significantly more diluted.

Additionally, little difference in cloud droplet burden is found between plumes where a fresh (ship10) or an aged (ship10A) size distribution was assumed at the point of emission. In accordance, marginal differences in cloud droplet number concentration $\left(N_{\mathrm{c}}\right)$ were simulated, as shown in Fig. 7. Although P75 is slightly higher in ship10, the median of $N_{\mathrm{c}}$ lies at $32 \mathrm{~cm}^{-3}$ in both simulations. This is consistent with the equivalent increase of aerosol number concentration within the size range of activation in these simulations. This result is contradictory to global studies (Righi et al., 2011; Peters et al., 2012), where a high sensitivity of the aerosolcloud interactions to the aging of the prescribed emissions was found. The cause for these different sensitivities remains to be addressed. It could be due to different treatments of the cloud or aerosol microphysics within the different models, or it may be attributable to the different microphysical aging of the plume allowed by the higher resolution.

Comparing the simulated changes in effective radius $R_{\text {eff }}$ (Fig. 7b) as well as $N_{\mathrm{c}}$ to in situ and surface remote sensing observations of ship tracks one finds, in general, a good agreement of the simulated and observed cloud response. 

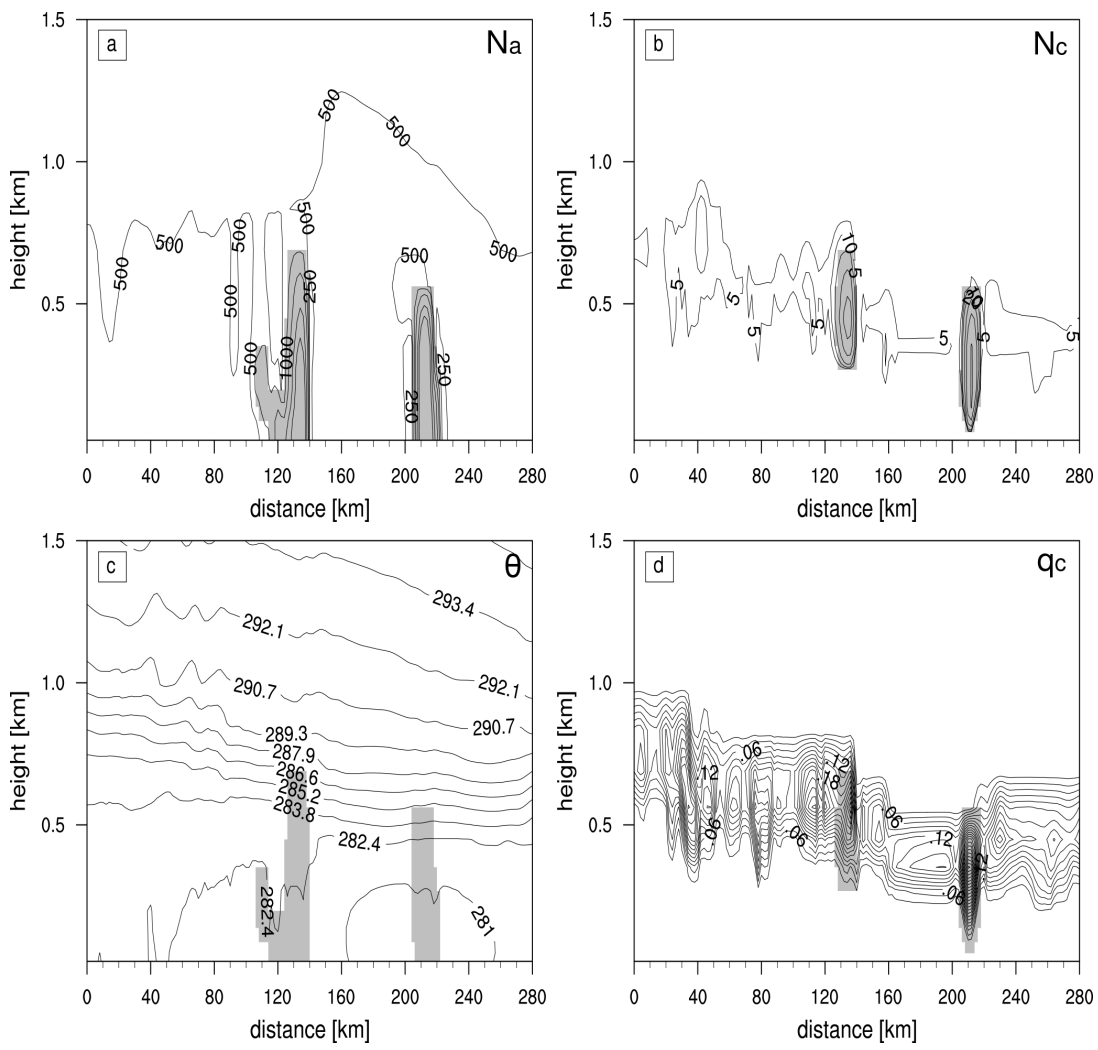

Figure 8. Vertical cross-sections (location shown in Fig. 6 row c) for (a) the total aerosol number concentration $N_{\mathrm{a}}\left[\mathrm{cm}^{-3}\right]$, (b) $N_{\mathrm{c}}\left[\mathrm{cm}^{-3}\right]$, (c) $\theta[\mathrm{K}]$ and (d) the liquid cloud water content $q_{\mathrm{c}}\left[\mathrm{g} \mathrm{kg}^{-1}\right]$. Each contour in (a) indicates a doubling of the concentration starting at $250 \mathrm{~cm}^{-3}$. In (b) the contour levels are: $2,5,10,50, \ldots$ every $50 \ldots, 350 \mathrm{~cm}^{-3} . \theta$ contours are given at an interval of $1.4 \mathrm{~K}$ and for $q_{\mathrm{c}}$ the contour spacing is $0.02 \mathrm{~g} \mathrm{~kg}^{-1}$. Grey shading in $(\mathbf{a}, \mathbf{c})$ indicates plume points and in $(\mathbf{b}, \mathbf{d})$ plume points where a significant cloud response was simulated as defined in Sect. 2.3.
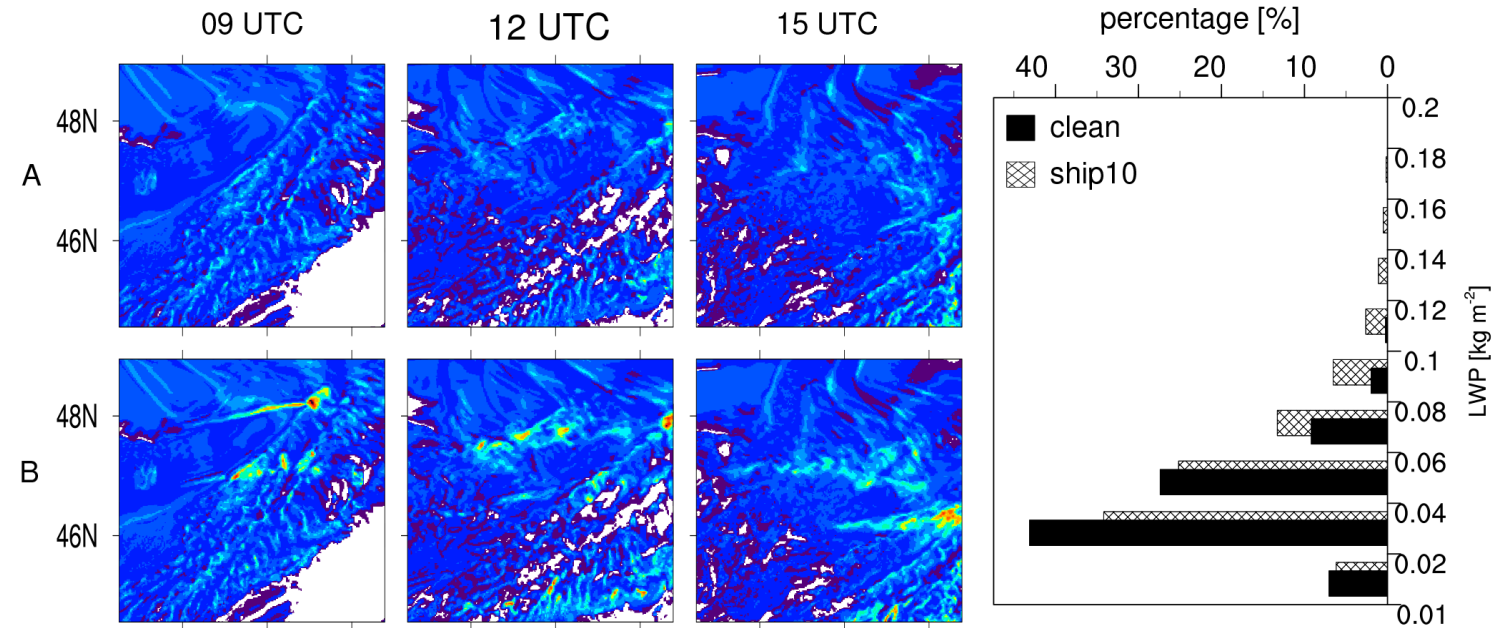

$10 \mathrm{~W} \quad 8 \mathrm{~W} \quad 6 \mathrm{~W}$

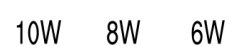

10W $8 \mathrm{~W} \quad 6 \mathrm{~W}$

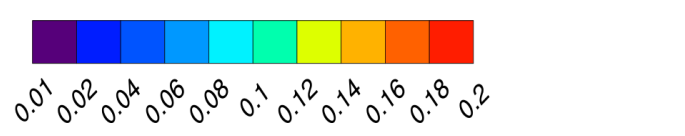

Figure 9. Liquid water path $\left[\mathrm{kg} \mathrm{m}^{-2}\right]$ is shown in the ship track domain for two simulations (row a: clean, row b: ship10) at 09:00, 12:00 and 15:00 UTC. AT 12:00 UTC the LWP histogram for the contour spacing is shown for clean and ship10 in addition for the displayed domain. 

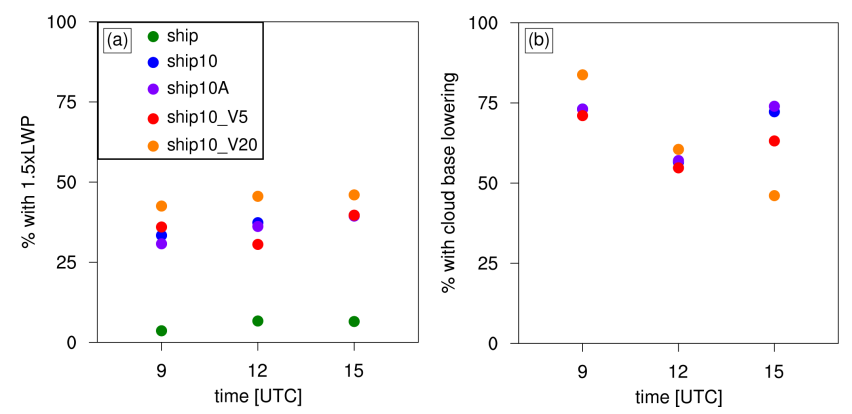

Figure 10. (a) Percentage of ship plume points of significant cloud response determined as in Fig. 7, where at least a $50 \%$ liquid water path (LWP) increase was detected. Given a $50 \%$ LWP increase in at least $25 \%$ of all plume points, the percentage of plume perturbed grid points which additionally displayed a cloud base lowering was computed and is shown in (b). A cloud base lowering is diagnosed for any change greater than $0 \mathrm{~m}$. Note that a cloud base lifting was not detected at any point.

The observed increase in cloud droplet number concentration ranges between $40 \mathrm{~cm}^{-3}$ (Hobbs et al., 2000) and $800 \mathrm{~cm}^{-3}$ (McComiskey et al., 2009), though most observed cloud droplet number concentrations lie within a narrower range of 40 to $200 \mathrm{~cm}^{-3}$ (Ferek et al., 1998; Hobbs et al., 2000; Hudson et al., 2000; Durkee et al., 2000).

Similarly the in situ observations of cloud effective radii measured in ship tracks ranged between 6 and $15 \mu \mathrm{m}$. This is almost identical to the range spanned by P25 and P75 in all simulations. Although these values were obtained for a range of environmental conditions which are not necessarily similar to the environmental conditions of this case study, these measurements provide a basis to demonstrate the realism of our simulated cloud response.

In line with the increase in $N_{\mathrm{c}}$, and the decrease of $R_{\mathrm{eff}}$ (Fig. 7), $\tau$ increases within the plume regions. In the ship10, ship10A and ship10_V5 simulations the response in $\tau$ varies between 6 to 10 at the track edges and 12 to 24 within the track centres. Within the ship simulation the response in $\tau$ is considerably weaker, following the considerably smaller perturbations to $N_{\mathrm{c}}$ and $R_{\text {eff }}$, at both 09:00 and 12:00 UTC. An increase in optical thickness of 8 to 10 was simulated within the considerably smaller plume areas. A slightly stronger response was simulated at 12:00 UTC in ship10_V20, where the increase in $\tau$ ranges between 8 to 14 within the plume regions.

Due to the significant increase of cloud optical thickness within the ship track regions, the top of the atmosphere (TOA) shortwave (SW) cloud radiative effect (CRE), defined as the difference between all-sky outgoing SW and clear-sky outgoing SW radiation at TOA, was changed. Averaged over the entire ship track domain, the TOA SW CRE (Fig. 7c) increased in magnitude by $19 \%$ in ship10, ship10A and ship10_V5. The stronger cooling of the clouds at the TOA is solely due to changes within the ship tracks them- selves, which cover at most $6 \%$ of the domain area, while the background TOA SW CRE variations were no larger than $5 \mathrm{Wm}^{-2}(\sim 3 \%)$ at any given time.

\subsection{Interplay between micro- and macrophysics}

In confined regions of the simulated ship tracks, the changes in microphysical properties were found to produce localised changes of macrophysical entities, such as cloud extent and in-cloud liquid water content $q_{\mathrm{c}}$. As is shown in Fig. 8, regions of increased $N_{\mathrm{c}}$ due to the ship exhaust aerosol were found to coincide with regions of increased $q_{\mathrm{c}}$. The localised increase of $q_{\mathrm{c}}$ is caused by the suppression of rain formation, since the influx of activated aerosol led to a significant decrease of cloud droplet size. Within the ship track domain, the stratocumulus deck is lightly precipitating with almost all precipitation evaporating before reaching the surface, thereby moistening the subcloud layer. Starting at 04:00 UTC, the rain water content within the ship track is reduced. At 09:00 UTC, the mean rain water content in ship10 within the ship track is reduced in the mean by $45 \%$ and by $38 \%$ at $12: 00$ UTC.

The resulting increase of liquid water path LWP is not only seen for the particular cross-section shown, but in several confined regions of the ship tracks (Fig. 9). The background LWP ranges between 0.02 and $0.08 \mathrm{~kg} \mathrm{~m}^{-2}$ and is found to remain constant throughout the day. Within the ship 10 simulation, the LWP is increased to 0.12 or even $0.16 \mathrm{~kg} \mathrm{~m}^{-2}$ in ship track regions (Fig. 9), which corresponds to almost a doubling of the LWP as compared to the background.

Changes in cloud liquid water content and cloud depth due to increased aerosol concentrations have been shown to affect cloud life time (Albrecht, 1989). Whether the cloud life time is increased or decreased depends fundamentally on the effect of drizzle suppression on the entrainment rate and the humidity in the free troposphere (Stevens et al., 1998). In general, precipitation acts to stabilise the boundary layer. In the case of a collapsed boundary layer such as the one analysed in this study, where cloud droplet number concentrations and accumulation size aerosol concentrations are extremely low, entrainment rates are believed to be small due to the weak radiative cloud top cooling generated by the optically thin clouds. Therefore, decreases in precipitation combined with a re-establishment of $\mathrm{CCN}$ have been shown to increase entrainment and lead to a re-growth of the previously collapsed boundary layer. However, entrainment rate parameterisations in most global and regional climate models are inadequate to capture such effects. During this case study we are not able to study possible effects of the ship exhaust on the PBL top as this process was found to occur on a typical timescale of the order of days (e.g. Berner et al., 2013). Due to advection of the air masses into regions of changed environmental conditions the impact of the ship exhaust on the stratiform cloud deck could only be studied for about $12 \mathrm{~h}$. 


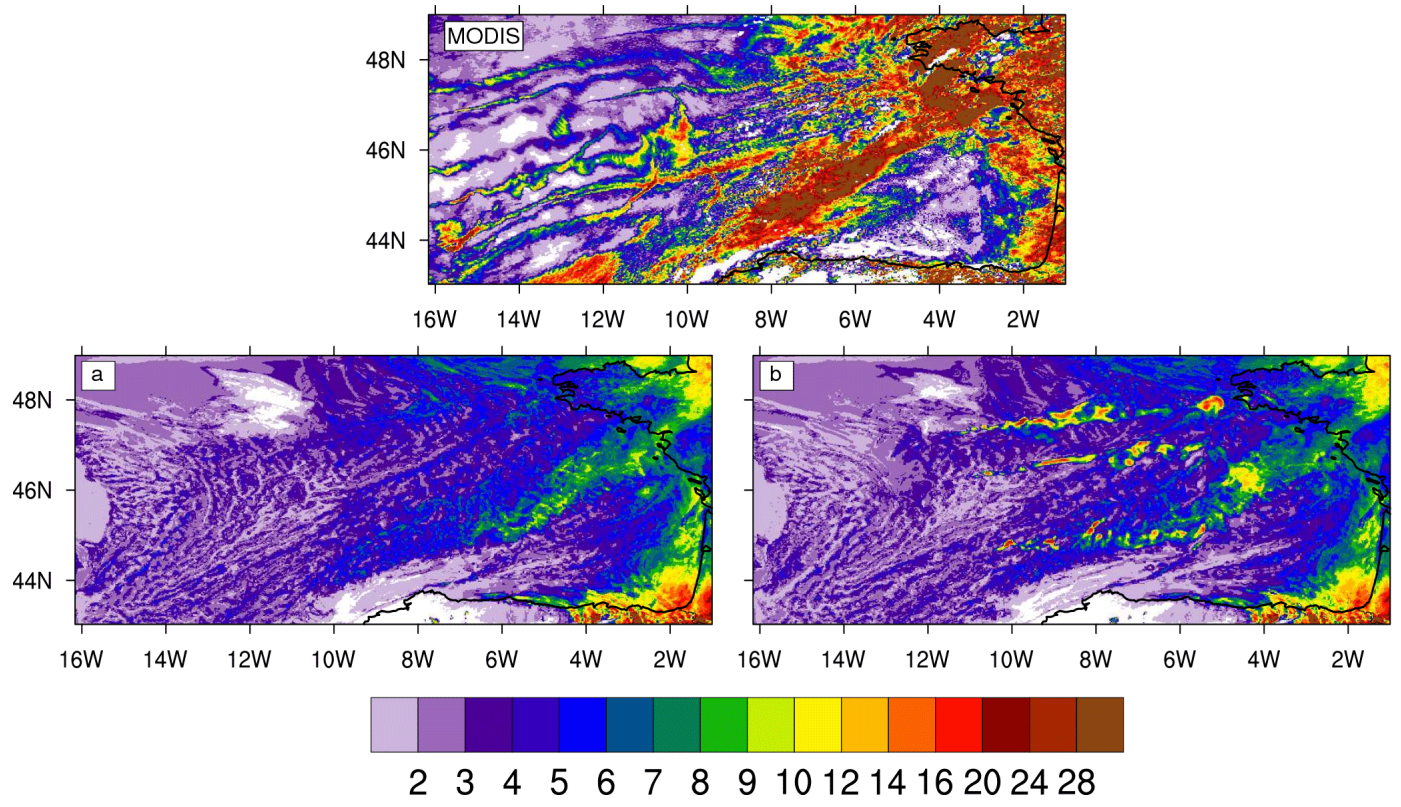

Figure 11. Comparison of cloud optical thickness observed by MODIS to simulated cloud optical thickness including grid-scale and subgridscale contributions for (a) clean, (b) ship10 at 12:00 UTC.

Nonetheless, increases of liquid water content within these regions were found to affect the simulated cloud depth, by lowering the cloud base. This is shown explicitly in Fig. 8d, where the cloud base is lowered significantly within the track regions. The occurrence of an increase in LWP with a combined decrease in cloud base height over the simulated period within the ship track domain is summarised in Fig. 10. As can be seen in Fig. 10a, a 50\% LWP increase is simulated in at least $25 \%$ of the ship track regions in all simulations but ship. Figure $10 \mathrm{~b}$ displays the simultaneous occurrence of cloud base lowering, given a $50 \%$ LWP increase. Between 09:00 and 15:00 UTC 50 to $80 \%$ of regions with increased LWP display an additional lowering of the cloud base, while a cloud base lifting was not simulated.

This phenomenon has previously been observed using balloon soundings during the Monterey Area Ship Track campaign (Durkee et al., 2000) campaign by Porch et al. (1999), where similar environmental conditions were encountered. A lowering of the cloud base by $\sim 50 \mathrm{~m}$ was measured. Based on their data alone, no clear explanation for this phenomenon could be found. However, Porch et al. (1999) hypothesised that the cloud base lowering was related to dynamical effects, such as adiabatic cooling in convective plumes originating from the ship. Microphysical effects related to increases in drizzle, on the other hand were perceived as unlikely. Our simulations suggest the cloud base lowering to be a consequence of drizzle suppression and the resulting localised increase of $q_{\mathrm{c}}$ within the PBL. As is shown in Table 3, the elevated increase in $N_{\mathrm{c}}$ ( $45 \%$ above ship track mean) in regions where a cloud base lowering is detected induces a larger decrease in the rain water content ( $30 \%$ below ship track mean) and hence a particularly pronounced LWP (22\% above ship track mean) and $\tau$ increase (24\% above ship track mean). As can be seen in Fig. 8, the cloud base is situated within the slightly stable PBL. Whilst the PBL stability and vertical mixing coefficients (not shown) are not affected by the emissions, the larger gradient in cloud water content itself, leads to an increased cloud water mixing below cloud base. There the cloud water evaporates, leading to a moistening of the subcloud layer. If a sufficient amount of cloud water is mixed downward, such that saturation is reached, the vertical cloud extent is increased. Additional cloud water condensation due to increased radiative cooling in the cloud layer within the enhanced LWP region was not simulated.

\subsection{Evaluation against observations}

The simulated cloud optical thickness, diagnosed in the visible spectrum, is compared to the MODIS observation for $\tau$ obtained at 12:00 UTC on 26 January 2003. Within the observation shown in Fig. 11, three characteristic features can be determined. Firstly, considerably higher values of optical thickness (with $\tau>20$ ) are detected over land than over the ocean. Secondly, a pre-frontal band structure passing through the domain, which stretches across the Bay of Biscay from $4^{\circ} \mathrm{W}, 47^{\circ} \mathrm{N}$ to $10^{\circ} \mathrm{W}, 44^{\circ} \mathrm{N}$ at 12:00 UTC, is characterised by $\tau$ values of similar magnitude. Finally, a region of ship tracks embedded within an optically thin stratified cloud layer $(\tau<2)$ located to the west of the pre-frontal band of convection was observed.

The optical thickness is shown in Fig. 11 for two simulations (clean and ship10) in comparison to the MODIS ob- 
Table 3. Overview of changes in microphysical (cloud droplet and activated aerosol number burdens), radiative $(\tau)$ and macrophysical entities (LWP, total water path (TWP) and rain water path (RWP)) averaged over the following and regions and simulations: the enhanced (50\% increase) LWP region in ship10, the track regions in ship10 and clean, and the background region for clean.

\begin{tabular}{lcccc}
\hline Entity & Enhanced LWP ship10 & Track ship10 & Track clean & Background clean \\
\hline Cloud droplet & & & & \\
Number burden $\left[\mathrm{cm}^{-2}\right]$ & 12622 & 8677 & 1644 & 1434 \\
Activated aerosol & & & & \\
Number burden $\left[\mathrm{cm}^{-2}\right]$ & 90194 & 87448 & 28808 & 26493 \\
$\tau$ & 8.4 & 6.8 & 4.34 & 3.8 \\
LWP $\left[\mathrm{kg} \mathrm{m}^{-2}\right]$ & 0.067 & 0.055 & 0.038 & 0.033 \\
RWP $\left[\mathrm{kg} \mathrm{m}^{-2}\right]$ & 0.007 & 0.01 & 0.017 & 0.016 \\
TWP $\left[\mathrm{kg} \mathrm{m}^{-2}\right]$ & 8.5 & 8.6 & 8.6 & 8.1 \\
\hline
\end{tabular}

servation. Only one of the simulations including ship emissions is shown here, as the two features outside the small ship track region are identical (qualitatively) in all simulations. The cloud response within the ship tracks for all other simulations is shown in Fig. 6 for the ship track domain.

The cloud optical thickness over land as well as within the convective band is strongly underestimated in all simulations. Causes for this low bias in $\tau$ can be manifold and can not be disentangled with confidence based on this observation alone. It might be caused by an underestimation in pollution, or vertical velocity in the simulations, which would lead to a low bias in either activated cloud droplet number concentration, cloud water or both. Although the issue has to be acknowledged, it is outside the scope of this work.

We now focus our analysis on the region west of the convective cloud band. The observed background optical thickness in this region ranges from less than 2 up to a value of 4 , which represents an optically very thin cloud sheet. The range of $\tau$ simulated within the background cloud compares well to observations. However, significantly more smallscale structures with higher values of optical thickness (3-4 instead of $\tau<2$ ) occur within the simulations than the observations. These structures are due to subgrid-scale cloud water produced by the shallow convection scheme. Therefore, with respect to the mean state, a slightly optically thicker background cloud sheet is simulated than observed.

The perturbation in $\tau$ along the observed ship tracks varies between 5-10 in one group of tracks and 10-24 in more pronounced ship tracks. Although the simulated and observed ship tracks cannot be compared one-to-one since the prescribed ship routes vary in space from the observations, a comparison in terms of the perturbation in $\tau$ as well as the track structure can be made.

The simulated cloud response in terms of optical thickness in all simulations containing ship emissions agrees well with observations. As was done for the observed ship tracks, the simulated cloud response along the ship tracks can be grouped into the same two classes. While simulations with a smaller prescribed ship emission flux (ship), or older ship tracks (ship10_V20) lead to a smaller perturbation in $\tau$ (i.e. 5-10), the remaining simulations produced ship tracks with a larger cloud response where $\tau$ ranges between 10 and 24 as in the observations.

Furthermore, the simulations and the observations are nearly identical in terms of horizontal track extent and length. The only exception might be ship, as the ship track segments where the aerosol perturbation is sufficient to create a detectable increase in $\tau$ with respect to the background seem to be underestimated in length compared to the observations.

\section{Conclusions}

In this study a new approach to study aerosol-cloud interactions and macroscopic feedbacks in ship tracks has been used. For a particular case study ship tracks were simulated in a real-case setup with the regional non-hydrostatic COSMO model for 26 January 2003 and evaluated against MODIS cloud optical thickness obtained at 12:00 UTC.

Numerous ship tracks were observed in this region, covered by a drizzling, optically thin cloud sheet $(\tau \leq 2)$ under very clean conditions with very few accumulation mode background aerosol. Such a regime had previously been identified as susceptible to aerosol perturbations, allowing the formation of ship tracks within the cloud sheet.

These simulations have shown that a regional model is able to capture key aspects of ship track formation and to simulate a realistic cloud response. After reaching cloud base (which was found to take roughly $1 \mathrm{~h}$ ), the aerosol coated by sulfate begin to interact with the cloud. Evaluation against observations showed the cloud microphysical response to be comparable to observations in terms of changes in cloud droplet number $\left(\Delta N_{\mathrm{c}} \leq 150 \mathrm{~cm}^{-3}\right)$ and effective radius $\left(\Delta R_{\text {eff }} \sim-5 \mu \mathrm{m}\right)$. Furthermore, all simulations with ship exhaust displayed at least a doubling of $\tau$ with respect to the background. The comparison of the simulations against MODIS showed the simulated cloud-radiative response to be realistic. 
The resulting cloud radiative effect is largely determined by the change in $\mathrm{CCN}$ due to the ship emissions. The $\mathrm{CCN}$ concentration in turn is intrinsically linked to the aerosol perturbation within the soluble Aitken and accumulation modes. These simulations showed the aerosol size distribution perturbation to be very sensitive to the emission flux and size. A scaling of the emission mass flux by a factor of 10 had to be applied to reproduce observed aerosol size distributions near the source, which defines the size distribution within the entire exhaust plume and hence the potential $\mathrm{CCN}$ perturbation by ship emissions. While some uncertainty remains with the observations, the dilution of literature ship emissions onto the grid scale, which provides a grid-scale mean perturbation to the system, may lead to a significant underestimation of their potential effects. However, the performed scaling of the emission fluxes leads to a considerable overestimation of peak concentrations in ship10. In this manner the simulations highlight the issues tied to analysing effects of a rapidly microphysically processed point-source aerosol emission with parameterisations based on grid-scale mean fields operating at discretised time steps. In order to determine the magnitude and sensitivity of the emission dilution effect, simulations for a range of computational resolutions, including LES resolution, would be highly desirable.

Although global studies are based on fundamentally different ship emission inventories than those used in this study, they are still restricted to area-weighted emission fluxes over grid box sizes of $\mathcal{O}(100) \mathrm{km}$. Furthermore, given atmospheric residence times of $\mathrm{SO}_{4}, \mathrm{BC}$ and $\mathrm{OC}$ of several days to a week, biases in the predicted aerosol number perturbation due to ship emissions could introduce significant uncertainties in radiative forcing estimates. Indeed it has been shown in global simulations, based on the same aerosol microphysical parameterisation, that a tenfold upscaling of the emission inventories did induce significant changes in microphysical and macrophysical quantities surpassing the background noise (Peters et al., 2014).

Besides the microphysical and radiative response, changes in cloud structure and liquid water content were simulated. The liquid water content was found to have increased by $50 \%$ in at least $25 \%$ of the ship tracks, which coincided with a cloud base lowering in over $70 \%$ at the early onset of ship track formation. By vertical mixing of cloud water within the boundary layer and evaporation below cloud base the condensation level was lowered in the simulations.

On the whole, these simulations give confidence in the realism of a multitude of simulated processes occurring predominantly on the parameterised scale. To further constrain parameterisations which are widely used in regional and global models using this kind of approach, a more comprehensive data set would be required. In order to attribute biases to particular parameterisations (turbulence, cloud and aerosol microphysics, radiation, shallow convection, etc.) simultaneous observations of the boundary layer and turbulent structure, ship emission, background aerosol concentrations and composition as well as cloud property measurements in and around the ship track would be needed, most of which were obtained during the Monterey Area Ship-Track campaign (e.g. Noone et al., 2000).

Acknowledgements. We wish to thank the Swiss National Supercomputing Centre (CSCS) for providing Cray XC30 platforms for the simulations of this study. Furthermore, we thank the COSMO consortium for code access, the German weather service (DWD) and MeteoSwiss for code maintenance and setup, as well as C2SM for source code support. In particular we would like to thank Dani Lüthi for his help on data handling and technical support.

Edited by: J. Quaas

\section{References}

Abdul-Razzak, H. and Ghan, S. J.: A parameterization of aerosol activation 2. Multiple aerosol types, J. Geophys. Res., 105, 68376844, 2000.

Ackerman, A. S., Toon, O. B., and Hobbs, P. V.: Dissipation of marine stratiform clouds and collapse of the marine boundary layer due to the depletion of cloud condensation nuclei by clouds, Science, 262, 226-229, 1993.

Albrecht, B. A.: Aerosols, cloud microphysics, and fractional cloudiness, Science, 245, 1227-1230, 1989.

Berner, A. H., Bretherton, C. S., Wood, R., and Muhlbauer, A.: Marine boundary layer cloud regimes and POC formation in a CRM coupled to a bulk aerosol scheme, Atmos. Chem. Phys., 13, 12549-12572, doi:10.5194/acp-13-12549-2013, 2013.

Bodas-Salcedo, A., Webb, M. J., Bony, S., Chepfer, H., Dufresne, J.-L., Klein, S. A., Zhang, Y., Marchand, R., Haynes, J. M., Pincus, R., and John, V. O.: COSP: A satellite simulation software for model assessment, B. Am. Meteorol. Soc., 92, 1023-1043, 2011.

Bott, A.: A positive definite advection scheme obtained by nonlinear renormalization of the advective fluxes, Mon. Weather Rev., 117, 1006-1015, 1989.

Chen, Y.-C., Christensen, M. W., Xue, L., Sorooshian, A., Stephens, G. L., Rasmussen, R. M., and Seinfeld, J. H.: Occurrence of lower cloud albedo in ship tracks, Atmos. Chem. Phys., 12, 8223-8235, doi:10.5194/acp-12-8223-2012, 2012.

Christensen, M. and Stephens, G.: Microphysical and macrophysical responses of marine stratocumulus polluted by underlying ships: 2. Impacts of haze on precipitating clouds, J. Geophys. Res., 116, D11203, doi:10.1029/2010JD014638, 2011.

Christensen, M. and Stephens, G.: Microphysical and macrophysical responses of marine stratocumulus polluted by underlying ships: evidence of cloud deepening, J. Geophys. Res., 117, D03201, doi:10.1029/2011JD017125, 2012.

Coakley, J. A., Bernstein, R. L., and Durkee, P. A.: Effect of ship track effluents on cloud reflectivity, Science, 237, 1020-1022, 1987.

Corbett, J. J.: Updated emissions from ocean shipping, J. Geophys. Res., 108, 4650, doi:10.1029/2003JD003751, 2003.

Dee, D. P., Uppala, S. M., Simmons, A. J., et al.: The ERA-Interim reanalysis: configuration and performance of the data assimilation system, Q. J. Roy. Meteor. Soc., 137, 553-597, 2011. 
Durkee, P. A., Noone, K. J., and Bluth, R. T.: The Monterey Area Ship Track Experiment, J. Atmos. Sci., 57, 2523-2541, 2000.

Ferek, R. F., Hegg, D. A., and Hobbs, P. V.: Measurements of shipinduced tracks in clouds off the Washington coast, J. Geophys. Res., 103, 23199-23206, doi:10.1029/98JD02121, 1998.

Foerstner, J. and Doms, G.: Runge-Kutta Time Integration and High-Order Spatial Discretization of Advection - A New Dynamical Core for the LMK, COSMO, COSMO Newsletter, No. 4, 168-176, 2004.

Folini, D. and Wild, M.: Aerosol emissions and dimming/brightening in Europe: sensitivity studies with ECHAM5-HAM, J. Geophys. Res., 116, D21104, doi:10.1029/2011JD016227, 2011.

Goren, T. and Rosenfeld, D.: Satellite observations of ship emissions induced transitions from broken to closed cell marine stratocumulus over large areas, J. Geophys. Res., 117, D17206, doi:10.1029/2012JD017981, 2012.

Guelle, W., Schulz, M., Balkanski, Y., and Dentener, F.: Influence of source formulation on modeling the atmospheric global distribution of sea salt aerosol, J. Geophys. Res., 106, 27509-27524, doi:10.1029/2001JD900249, 2001.

Hobbs, P. V., Garrett, T. J., Ferek, R. J., Strader, S. R., Hegg, D. A., Frick, G. M., Hoppel, W. A., Gasparovic, R. F., Russel, L. M., Johnson, D. W., O’Dowd, C., Durkee, P. A., Nielsen, K. E., and Innis, G.: Emissions from ships with respect to their effects on clouds, J. Atmos. Sci., 57, 2570-2590, 2000.

$\mathrm{Hu}, \mathrm{Y}$. X. and Stamnes, K.: An accurate parameterization of the radiative properties of water clouds suitable for use in climate models, J. Climate, 6, 728-742, 1993.

Hudson, J., Garrett, T. J., Hobbs, P. V., and Strader, S. R.: Cloud condensation nuclei and ship tracks, J. Atmos. Sci., 57, 26962706, 2000.

Kazil, J., Wang, H., Feingold, G., Clarke, A. D., Snider, J. R., and Bandy, A. R.: Modeling chemical and aerosol processes in the transition from closed to open cells during VOCALS-REx, Atmos. Chem. Phys., 11, 7491-7514, doi:10.5194/acp-11-74912011, 2011.

King, M. D., Tsay, S.-C., Platnick, S. E., Wang, M., and Liou, K.N.: Cloud Retrieval Algorithms for MODIS: Optical Thickness, Effective Particle Radius and Thermodynamic Phase, NASA, No. ATBD-MOD-05, 1998.

Kinne, S., Schulz, M., Textor, C., Guibert, S., Balkanski, Y., Bauer, S. E., Berntsen, T., Berglen, T. F., Boucher, O., Chin, M., Collins, W., Dentener, F., Diehl, T., Easter, R., Feichter, J., Fillmore, D., Ghan, S., Ginoux, P., Gong, S., Grini, A., Hendricks, J., Herzog, M., Horowitz, L., Isaksen, I., Iversen, T., Kirkevåg, A., Kloster, S., Koch, D., Kristjansson, J. E., Krol, M., Lauer, A., Lamarque, J. F., Lesins, G., Liu, X., Lohmann, U., Montanaro, V., Myhre, G., Penner, J., Pitari, G., Reddy, S., Seland, O., Stier, P., Takemura, T., and Tie, X.: An AeroCom initial assessment - optical properties in aerosol component modules of global models, Atmos. Chem. Phys., 6, 1815-1834, doi:10.5194/acp-6-1815-2006, 2006.

Lack, D. A., Corbett, J. J., Onasch, T., Lerner, B., Massoli, P., Quinn, P. K., Bates, T. S., Covert, D. S., Coffman, D., Sierau, B., Herndon, S., Allan, J., Baynard, T., Lovejoy, E., Ravishankara, A. R., and Williams, E.: Particulate emissions from commercial shipping: chemical, physical and optical properties,
J. Geophys. Res., 114, D00F04, doi:10.1029/2008JD011300, 2009.

Lauer, A., Eyring, V., Hendricks, J., Jöckel, P., and Lohmann, U.: Global model simulations of the impact of ocean-going ships on aerosols, clouds, and the radiation budget, Atmos. Chem. Phys., 7, 5061-5079, doi:10.5194/acp-7-5061-2007, 2007.

Lin, H. and Leaitch, W. R.: Development of an in-cloud aerosol activation parameterization for climate modeling, in: Proc. WMO Workshop on Measurements of Cloud Properties for Forecasts of Weather and Climate, edited by: Baumgardner, D., and Raga, G., Mexico City, Mexico, 23-27 June 1997, 328-335, 1997.

Lohmann, U.: Possible aerosol effects on ice clouds via contact nucleation, J. Atmos. Sci., 59, 647-656, 2002.

Lohmann U. and Stier P. and Hoose C. and Ferrachat S. and Kloster S. and Roeckner E., and Zhang J.: Cloud microphysics and aerosol indirect effects in the global climate model ECHAM5-HAM, Atmos. Chem. Phys., 7, 3425-3446, 2007, http://www.atmos-chem-phys.net/7/3425/2007/.

Lund, M. T., Eyring, V., Fuglestvedt, J., Hendricks, J., Lauer, A., Lee, D., and Righi, M.: Global-mean temperature change from shipping toward 2050: improved representation of the indirect aerosol effect in simple climate models, Environ. Sci. Technol., 46, 8868-8877, doi:10.1021/es301166e, 2012.

McComiskey, A., Feingold, G., Frisch, A. S., Turner, D. D., Miller, M. A., Chiu, J. C., Min, Q., and Ogren, J. A.: An assessment of aerosol-cloud interactions in marine stratus clouds based on surface remote sensing, J. Geophys. Res., 114, D09203, doi:10.1029/2008JD011006, 2009.

Moldanová, J., Fridell, E., Popovicheva, O., Demirdjian, B., Tishkova, V., Faccinetto, A., and Focsa, C.: Characterisation of particulate matter and gaseous emissions from a large ship diesel engine, Atmos. Environ., 43, 2632-2641, 2009.

Murphy, S. M., Agrawal, H., Sorooshian, A., Padró, L. T., Gates, H., Hersey, S., Welch, W. A., Jung, H., Miller, J. W., D. R. Cocker III, A. N., Jonsson, H. H., Flagan, R. C., and Seinfeld, J.: Comprehensive simultaneous shipboard and airborne characterization of exhaust from a modern container ship at sea, Environ. Sci. Technol., 43, 4626-4640 doi:10.1021/es802413j, 2009.

Myhre, G., Shindell, D., Bréon, F.-M., et al.: Climate Change 2013: The Physical Science Basis. Contribution of Working Group I to the Fifth Assessment Report of the Intergovernmental Panel on Climate Change, Cambridge University Press, Cambridge, UK and New York, USA, 2013.

Nam, C., Bony, S., Dufresne, J.-L., and Chepfer, H.: The "too few, too bright" tropical low-cloud problem in CMIP5 models, Geophys. Res. Lett., 39, L21801, doi:10.1029/2012GL053421, 2012.

Nenes, A. and Seinfeld, J. H.: Parameterization of cloud droplet formation in global climate models, J. Geophys. Res., 108, 4415, doi:10.1029/2002JD002911, 2003.

Noone, K. J., Johnson, D. W., Taylor, J. P., Ferek, R. J., Garret, T., Hobbs, P. V., Durkee, P. A., Nielson, K., Platnick, S., King, M. D., Öström, E., O’Dowd, C. D., Smith, M. H., Russel, L. M., Flagan, R. C., Seinfeld, J. H., DeBock, L., van Grieken, R., Hudson, J. G., Brooks, I. M., Gasparovic, R. F., and Pockalny, R. A.: A case study of ship track formation in a polluted boundary layer, J. Atmos. Sci., 57, 2748-2764, 2000.

Nozawa T. and Nagashima T. and Ogura T. and Yokohata T. and Okada N. and Shiogama M.: Climate Change Simulations With a Coupled Ocean-Atmosphere GCM Called the Model for In- 
terdisciplinary Research on Climate: MIROC, CGER's Supercomputer Monogr. Rep. Ser., Vol. 12, 79 pp., Natl. Inst. for Environ. Stud., Tsukuba, Jpn., available at: //www.cger.nies.go.jp/ publications/report/i073/I073.pdf, 2007.

Partanen, A. I., Laakso, A., Schmidt, A., Kokkola, H., Kuokkanen, T., Pietikäinen, J.-P., Kerminen, V.-M., Lehtinen, K. E. J., Laakso, L., and Korhonen, H.: Climate and air quality tradeoffs in altering ship fuel sulfur content, Atmos. Chem. Phys., 13, 12059-12071, doi:10.5194/acp-13-12059-2013, 2013.

Peters, K., Quaas, J., and Graß1, H.: A search for large-scale effects of ship emissions on clouds and radiation in satellite data, J. Geophys. Res., 116, D24205, doi:10.1029/2011JD016531, 2011.

Peters, K., Stier, P., Quaas, J., and Graß1, H.: Aerosol indirect effects from shipping emissions: sensitivity studies with the global aerosol-climate model ECHAM-HAM, Atmos. Chem. Phys., 12, 5985-6007, doi:10.5194/acp-12-5985-2012, 2012.

Peters, K., Quaas, J., Stier, P., and Graß1, H.: Processes limiting the ermergence of detectable aerosol indirect effects on tropical warm clouds in global aerosol-climate model and satellite data, Tellus B, 66, 24054, doi:10.3402/tellusb.v66.24054, 2014.

Petzold, A., Hasselbach, J., Lauer, P., Baumann, R., Franke, K., Gurk, C., Schlager, H., and Weingartner, E.: Experimental studies on particle emissions from cruising ship, their characteristic properties, transformation and atmospheric lifetime in the marine boundary layer, Atmos. Chem. Phys., 8, 2387-2403, doi:10.5194/acp-8-2387-2008, 2008.

Platnick, S., King, M. D., Ackermann, S. A., Menzel, W. P., Baum, B. A., Riedi, J. C., and Frey, R. A.: The MODIS cloud products: algorithms and examples from Terra, IEEE T. Geosci. Remote, 41, 459-473, doi:10.1109/TGRS.2002.808301, 2003.

Porch, W., Borys, R., Durkee, P., Gasparovic, R., Hooper, W., Hindman, E., and Nielsen, K.: Observations of ship tracks from shipbased platforms, J. Appl. Meteorol., 38, 69-81, 1999.

Possner, A., Zubler, E., Fuhrer, O., Lohmann, O., and Schär, C.: A case study in modeling low-lying inversions and stratocumulus cloud cover in the Bay of Biscay, Weather Forecast., 29, 289304, 2014.

Righi, M., Klinger, C., Eyring, V., Hendricks, J., Lauer, A., and Petzold, A.: Climate impact of biofuels in shipping: global model studies of the aerosol indirect effect, Environ. Sci. Technol., 45, 3519-3525, 2011.

Ritter, B. and Geleyn, J. F.: A comprehensive radiation scheme for numerical weather prediction models with potential applications in climate simulations, Mon. Weather Rev., 120, 303-325, 1992.

Roeckner E. and Stier P. and Feichter J. and Kloster S. and Esch M. and Fischer-Bruns I.: Impact of carbonaceous aerosol emissions on regional climate change, 27, 553-571, 2006.

Schreier, M., Mannstein, H., Eyring, V., and Bovensmann, H.: Global ship track distribution and radiative forcing from 1 year of AATSR data, Geophys. Res. Lett., 34, L17814, doi:10.1029/2007GL030664, 2007.

Seifert, A. and Beheng, K. D.: A two-moment cloud microphysics parameterization for mixed-phase clouds. Part 1: Model description, Meteorol. Atmos. Phys., 92, 45-66, 2006.

Stevens, B. and Feingold, G.: Untangling aerosol effects on clouds and precipitation in a buffered system, Nature, 461, 607-613, 2009

Stevens, B., Cotton, W. R., Feingold, G., and Moeng, C. H.: Large-eddy simulations of strongly precipitating, shallow, stratocumulus-topped boundary layers, J. Atmos. Sci., 55, 36163638, 1998.

Stier, P. and Feichter, J. and Kinne S. and Kloster S. and Vignati E. and Wilson J. and Ganzeveld L. and Tegen L. and Tegen I. and Werner M. and Balkanski Y. and Schulz M. and Boucher O. and Minikin A. and Petzold A.: The aerosol climate model ECHAM5-HAM, Atmos. Chem. Phys., 5, 1125-1156, 2005, http://www.atmos-chem-phys.net/5/1125/2005/.

Stier P. and Feichter J. and Roeckner E. and Kloster S. and Esch M.: The evolution of the global aerosol system in a transient climate simulation from 1860 to 2100, Atmos. Chem. Phys., 6, 30593076, 2006, http://www.atmos-chem-phys.net/6/3059/2006/.

Tiedtke, M.: A comprehensive mass flux scheme for cumulus parameterization in large-scale models, Q. J. Roy. Meteor. Soc., 117, 1779-1800, 1989.

Twomey, S.: Pollution and planetary albedo, Atmos. Environ., 25, 2435-2442, 1974.

Uppala, S. M., Kallberg, P. W., and Simmons, A. J.: The ERA-40 re-analysis, Q. J. Roy Meteor. Soc., 131, 2961-3012, 2005.

Verzijlbergh, R. A., Jonker, H. J. J., Heus, T., and VilàGuerau de Arellano, J.: Turbulent dispersion in cloudtopped boundary layers, Atmos. Chem. Phys., 9, 1289-1302, doi:10.5194/acp-9-1289-2009, 2009.

Vignati, E., Wilson, J., and Stier, P.: M7: An efficient size-resolved aerosol microphysics module for large-scale aerosol transport models, J. Geophys. Res., 109, D22202, doi:10.1029/2003JD004485, 2004.

Vutukuru, S. and Dabdub, D.: Modeling the effects of ship emissions on coastal air quality: a case study of southern California, Atmos. Environ., 42, 3751-3764, 2008.

Wang, H. and Feingold, G.: Modeling mesoscale cellular structures and drizzle in marine stratocumulus. Part II: Microphysics and dynamcis of the boundary region between open and closed cells, J. Atmos. Sci., 66, 3257-3275, 2009.

Wang, H., Rasch, P. J., and Feingold, G.: Manipulating marine stratocumulus cloud amount and albedo: a process-modelling study of aerosol-cloud-precipitation interactions in response to injection of cloud condensation nuclei, Atmos. Chem. Phys., 11, 4237-4249, doi:10.5194/acp-11-4237-2011, 2011.

Wicker, L. J. and Skamarock, W. C.: Time-splitting methods for elastic models using forward time schemes, Mon. Weather Rev., 130, 2088-2097, 2002.

Wood, R.: Review: stratocumulus clouds, Mon. Weather Rev., 140, 2373-2423, 2012.

Wood, R., Bretherton, C. S., Leon, D., Clarke, A. D., Zuidema, P., Allen, G., and Coe, H.: An aircraft case study of the spatial transition from closed to open mesoscale cellular convection over the Southeast Pacific, Atmos. Chem. Phys., 11, 2341-2370, doi:10.5194/acp-11-2341-2011, 2011.

Zubler, E., Folini, D., Lohmann, U., Lüthi, D., Mühlbauer, A., Pousse-Nottelmann, S., Schär, C., and Wild, M.: Implementation and evaluation of aerosol and cloud microphysics in a regional climate model, J. Geophys. Res., 116, D02211, doi:10.1029/2010JD014572, 2011. 